\title{
Seismic microzonation in a complex volcano-tectonic setting: the case of northern and western Ischia Island (southern Italy)
}

\author{
Marco Mancini (1), Maria Chiara Caciolli $(1,6)$, Iolanda Gaudiosi (1), Giorgio Andrea Alleanza (2), \\ Giuseppe Cavuoto (3), Monia Coltella (1), Giuseppe Cosentino (4), Vincenzo Di Fiore (3), \\ Anna d’Onofrio (2), Francesco Gargiulo (2), Giuliano Milana (5), Andrea Pietrosante (1), \\ Pier Paolo Pompa (2), Francesco Silvestri (2) \& Maurizio Vassallo (5)
}

\section{ABSTRACT}

On August 21, 2017, the volcanic island of Ischia was struck by a Mw 3.9 (http://cnt.rm.ingv.it/event/16796811) earthquake which caused two victims and heavy damages on wide portions of the Casamicciola Terme, Lacco Ameno and Forio municipalities.

Following the Decree 1/2018 of the Government Commission for the reconstruction of damaged areas of Ischia Island, a Grade 3 Seismic Microzonation study was committed by each municipality to private consultants, who were scientifically supported by a multidisciplinary team of geologists, geophysicists and geotechnical engineers from CNR, INGV and University of Naples "Federico II".

The existing data from previous geological and geotechnical investigations were integrated with the results of new geo-lithological surveys and geophysical measurements (HVSR, MASW, Down hole tests) carried out by the consultants. The whole amount of data was quality checked, homogenized and collected in a SQLite/SpatiaLite geodatabase using a OGIS open source software by the support team.

A geo-lithological map of northern and western sides of the island was then produced, and the results of routine geophysical tests were coupled with those of seismic $2 \mathrm{D}$ ambient vibration arrays, to obtain shear wave velocity profiles (several hundreds of meters deep) down to the seismic bedrock, made of lithic tuffs and lavas, and to define its buried morphology. This in turn enabled to draw a map of seismically homogeneous microzones of the entire study area. Cyclic torsional shear tests were carried out on 10 undisturbed soil samples, mainly taken from epiclastic cover deposits, to characterize their non-linear behavior to be adopted for seismic response analyses.

These latter were carried out along 1D profiles characterizing each microzone and along selected 2D cross sections running from the Mount Epomeo to the coast. The dynamic analyses allowed to detect and map areas characterized by variable amplification factors, of spectral accelerations throughout different ranges of periods $(0.1-$ $0.5 \mathrm{~s}, 04 .-0.8 \mathrm{~s}, 0.7-1.1 \mathrm{~s}$ ). The zones most prone to site amplification are those corresponding to localized graben-like depressions at the toe of Mount Epomeo, such as Maio neighborhood of Casamicciola, where thickened epiclastic covers are entrenched into blocks of uplifted bedrock and where a combination of 1D stratigraphic amplification and 2D reflection and diffraction effects is expected.

(1) CNR IGAG Consiglio Nazionale delle Ricerche, Istituto di Geologia Ambientale e Geoingegneria, CNR Area della Ricerca Roma 1 - Montelibretti, Via Salaria km 29,300, 00015 Monterotondo Scalo (Rome), Italy.

(2) Università degli Studi di Napoli Federico II, Dipartimento di Ingegneria Civile, Edile e Ambientale,Via Claudio 21, 80125 Naples, Italy.

(3) CNR ISPC, Consiglio Nazionale delle Ricerche, Istituto di Scienze del Patrimonio Culturale, Via Cardinale Guglielmo Sanfelice 8 , 80134 Naples, Italy.

(4) CNR IGG, Consiglio Nazionale delle Ricerche, Istituto di Geoscienze e Georisorse, Area CNR, Via G. Moruzzi 1, 56124 Pisa, Italy.

(5) INGV, Istituto Nazionale di Geofisica e Vulcanologia, Via di Vigna Murata 605, 00143 Rome, Italy.

(6) Università degli Studi di Perugia, Dipartimento di Fisica e Geologia, Via Alessandro Pascoli s.n.c., 06123 Perugia, Italy. Corresponding author e-mail: marco.mancini@igag.cnr.it
KEY WORDS: Grade 3 seismic microzonation, Ischia, numerical modelling, site amplification.

\section{INTRODUCTION}

Many decades of research and studies focused on the damage distribution after earthquakes clearly highlight the role of local geological and geotechnical conditions on the distribution of ground motion at surface. The aim of a Seismic Microzonation (SM) is the analysis and representation, for a given urban territory, of the spatial distribution of a ground motion parameter including or representing soil amplification in free field conditions. Therefore, a seismic microzonation can be considered an effective tool supporting both the emergency management and the land use planning at the urban scale. A well-established SM methodology, currently shared by international (e.g., ISSMGE-TC4, 1999) and national (GRUPPo di LAVORO MS, 2008; SM Working Group, 2015) guidelines, involves a multilevel approach characterized by an increasing level of detail, directly proportional to the accuracy of the subsoil characterization and to the degree of definition of the reference seismic motion. In particular, SM of Grade (or Level) 3 deals with the numerical quantification of the seismic amplification within microzones, previously defined on the basis of the homogeneity of their local subsoil layering and of a geophysical-geotechnical characterization of the bedrock and the overriding soil. The method starts from the assumption that the results of $1 \mathrm{D}$ and $2 \mathrm{D}$ seismic response analyses carried out along distinctive vertical profiles or geo-lithological cross sections can be extended to the whole analyzed microzone. The result is a reliable spatialization of seismic amplification parameters, essential for correct Urban Planning Strategies and Seismic Risk Mitigation Policies (Albarello, 2017; Moscatelli et alii, 2020).

This paper illustrates the Grade 3 SM studies concerning the municipalities of Casamicciola Terme, Lacco Ameno and Forio (Island of Ischia, Naples, Italy), affected by the 21 August 2017 earthquake (Mw 3.9; $2 \mathrm{~km}$ depth; http://iside.rm.ingv.it/en/event/16796811), which caused two victims and heavy damages to a large number of buildings mostly concentrated in the "Zona Rossa" (Red Zone) area of the Casamicciola municipality (Fig. 1). 
Ground acceleration was $0.28 \mathrm{~g}$ at the Seismic Station IV.IOCA Ischia-Osservatorio Casamicciola (Fig. 1), on the east-west component.

Two distinct survey campaigns started soon after the event. First the OCDPC 476/2017 Decree of the Italian Civil Protection Department (OCDPC, 2017) promoted studies on these territories aimed at defining the geolithological setting and collecting geophysical data, in view of subsequent SM studies. The synthesis of borehole and literature data on the complex stratigraphy and volcano-tectonics of the island, coupled with results of the geophysical investigations (seismic noise measurements, MASW tests, seismic 2D ambient vibration arrays), allowed to identify the depth and buried morphology of the bedrock formations and cover units (CAVINATO et alii; MANCINI et alii, 2019). Results from those preliminary studies, integrated with previous detailed studies (VEzzoli, 1988; Tibaldi \& Vezzoli, 1998; 2004; Sbrana \& Toccaceli, 2011), are at the base of the geological and geo-lithological reconstructions proposed in the present study.

The following Decree 1/2018, issued by the Government Commissioner for reconstruction of damaged territories of the Island of Ischia (Presidenza Del Consiglio Dei Ministri, 2018), planned Grade 3 SM studies on those areas by assigning the task to private consultants. These were coordinated with a team of researchers from CNR (IGAG and ISMAR), INGV, and University of Naples "Federico II" (DICEA), who provided a scientific support for integrating the activity of the consultants with geotechnical and geophysical tests and with numerical modelling, and for the final validation of the study results. The SM studies exclusively focused on the amplification of the transient ground motion, leaving aside the seismic permanent deformation and failure (slope instability, liquefaction, or densification).

The seismic hazard, the high buildings density and the massive touristic affluence on the island, make Ischia a portion of the national territory where it is important to have studies specifically addressed to reduce seismic risk. In addition, this is one of the few studies of SM and site response in Italy developed in volcanic environment (Azzaro et alii, 2010; Licata et alii, 2016, 2019; AвATE et alii, 2020; Moscatelli et alii, 2021).

\section{HISTORICAL SEISMICITY AND COMPARISON WITH THE 21 AUGUST 2017 EVENT}

The island of Ischia is the top portion of a wide volcanic complex and its seismic hazard is controlled by the local volcanic setting in addition to the activity of the SZ928 (Ischia-Vesuvio) seismogenic zone (Meletti et alii, 2006, 2008; Sтuссні et alii, 2011). This latter caused the recent event and likely also the largest earthquake recorded, occurred in 1883, with a magnitude Mw ranging in literature from 4.3 to 5.8 (SELVA et alii, 2021, and references therein). The 1883 event, occurred during the touristic season, induced more than 2000 casualities (CuBELLIS \& LuONGO, 1998a) and a huge damage (destruction of $80 \%$ of buildings) corresponding to a MCS intensity as high as X.

Since this major event the Italian seismologist Mercalli (De Rossi, 1884; Guidoboni et alii, 2018) and, afterwards the two engineers, Giordano and Comotto, charged for a new building code definition (MarotTa et alii, 2019), recommended the construction of one storey new buildings, preferably located on flat sites or at least on gentle slopes to avoid local amplification effects (topographic and stratigraphic). The inhomogeneous distribution of the damages caused by the 1883 earthquake, in fact, was already observed where soft soils crop out (CARLINO et alii, 2010), suggesting the role of site effects in influencing the damage patterns.

These effects were further confirmed by the 21 August 2017 earthquake, which was characterized by a maximum macroseismic intensity equal to 8 (EMS scale, GRÜNTHAL, 1998; Azzaro et alii, 2017). A corresponding MCS intensity (CANCANI, 1904; SiEBERG, 1912) value of VIII may be inferred converting the EMS intensity by using the relationship of Musson et alii (2010). The two MCS intensity maps, as well as the two isoseismal maps, for the largest and the last earthquakes are shown in figures $1 \mathrm{c}$ and $\mathrm{d}$. Despite the different values of maximum MCS intensity in the affected area (likely due to source directivity and to the attempt carried out after 1883 to improve the performance of ordinary unreinforced masonry structures), the maximum damage due to both the earthquakes was always detected in a rather limited area, between the municipalities of Casamicciola Terme and Lacco Ameno.

Damages in the 1883 event also affected the centre of Forio, together with the southernmost of its hamlets, Panza, while slightest damages were observed in the same locations during the 2017 event.

\section{GEOLOGICAL SETTING}

The Island of Ischia is characterized by an intense volcanic activity spanning at least the last $150 \mathrm{ky}$, from the latest middle Pleistocene to the Present, basing on outcropping and shallow subsoil stratigraphy (VEzzoLI, 1988; SBRANA et alii, 2018 with references). Several eruptive phases, with main effusive and explosive events, were alternated with periods of volcanic quiescence and active volcano-tectonic pulses, triggering caldera collapses with intra-caldera basin subsidence and subsequent rapid uplift movements. The strong seismicity, widespread slope instabilities and hydrothermal phenomena result from the intense endogenous activity affecting the island.

The present physiography of the island derives from the main phases of volcano-tectonic evolution. In the center of the island the Mount Epomeo stands $789 \mathrm{~m}$ above sea level, which represents an intra-caldera resurgent block (Tibaldi \& Vezzoli 1998; 2004; Acocella \& Funiciello, 1999) bounded by hilly piedmont relieves (Figs. $2 \mathrm{a}$ and b), gently undulated with hummocks on the western flank (Forio), terraced and abruptly interrupted by narrow and deep valleys on the northern side (Casamicciola, Lacco Ameno). Along the coastal belt strandplains and terraces alternate with high rocky cliffs.

The oldest rocks, composed of alternated lavas and tuffs (approximately 150-75 ky old), represent the substratum for all the younger overlying volcanosedimentary successions, and crop out along the coastal promontories (Punta Imperatore-Campotese, Monte Vico) as remnants of a wide elliptic caldera rim (Figs. 2c and 3). After the caldera collapsed, about $75 \mathrm{ky} \mathrm{bp,} \mathrm{the} \mathrm{internal}$ basin was filled firstly by marine sediments (Cava Celario unit; Sbrana \& Toccaceli, 2011) and then by the Mount 

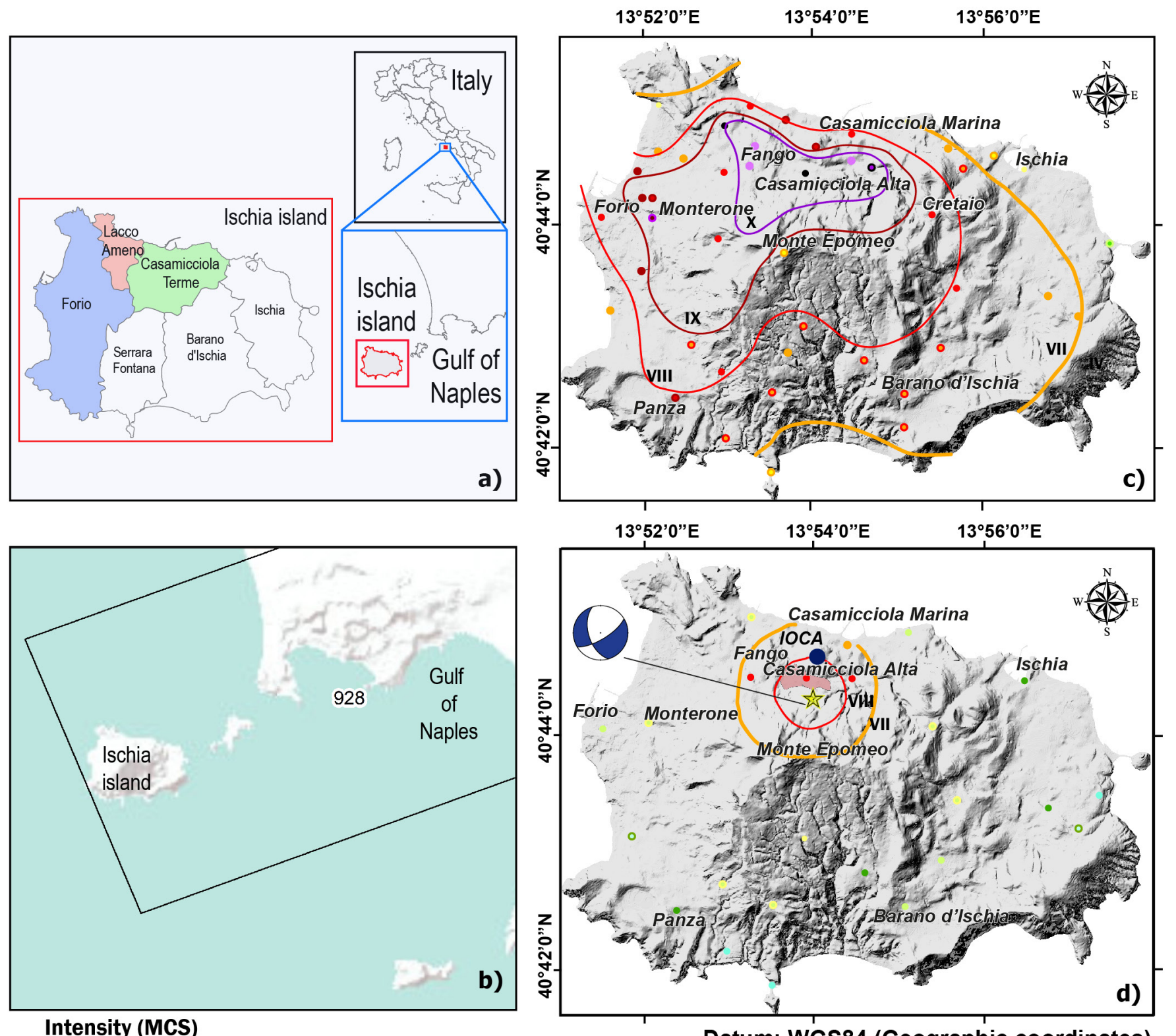

\begin{tabular}{|c|c|}
\hline ite & \\
\hline & \\
\hline$x$ & $\begin{array}{l}\qquad I X-\rangle \\
- \text { VIII }\end{array}$ \\
\hline & - VII- \\
\hline VI-VI & $\begin{array}{l}\mathrm{VI} \\
\mathrm{V}-\mathrm{VI}\end{array}$ \\
\hline & - IV \\
\hline IV-V & ○ III- \\
\hline
\end{tabular}

Datum: WGS84 (Geographic coordinates)

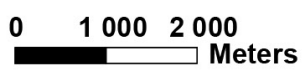

Red zone IOCA

seismic station

Fig. 1 - a) Localization of the study area with the three investigated municipalities: Casamicciola Terme, Lacco Ameno and Forio. b) Localization of the macrozone MZ928 (MELETTI et alii, 2006). c) MCS intensity map of the largest 1883 earthquake of Ischia: MCS point locations and values are retrieved from the revision proposed by SELVA et alii (2021). Isoseismals from CuBELLIS \& LuONGO (1998b) are also superimposed to the shaded relief map of the Ischia Island. d) MCS Intensity map of the 2017 earthquake: MCS point locations are retrieved from the revision proposed by SELVA et alii (2021), while corresponding MCS values were inferred converting the EMS (GRÜNTHAL, 1998) intensities proposed by AzzARO et alii (2017) according to the relationship of Musson et alii (2010). Isoseismals from VERDERAMEet alii (2017) are also superimposed to the shaded relief map of the Ischia island. Yellow star represents the instrumental epicentral location of the 2017 event (available at the INGV website: http://cnt. rm.ingv.it/event/16796811).

Epomeo Green Tuff Auct. This is a more than $300 \mathrm{~m}$ thick ignimbrite, extruded at about 60-50 ky, composing the central massif of Mount Epomeo, and overlain by sandpebble sized epiclastites (tuffite) of submarine apron environment (Colle Ietto and Campomanno units; SBRANA
\& Toccaceli, 2011) and by offshore silt and clays (Cava Leccie unit; Sbrana \& TocCaceli, 2011), totally up to $150 \mathrm{~m}$ in thickness. In the Forio area, the Mount Epomeo Green Tuff Auct. is overlain by the Citara Tuffs (45-42 ky old) and by nearshore sands. 

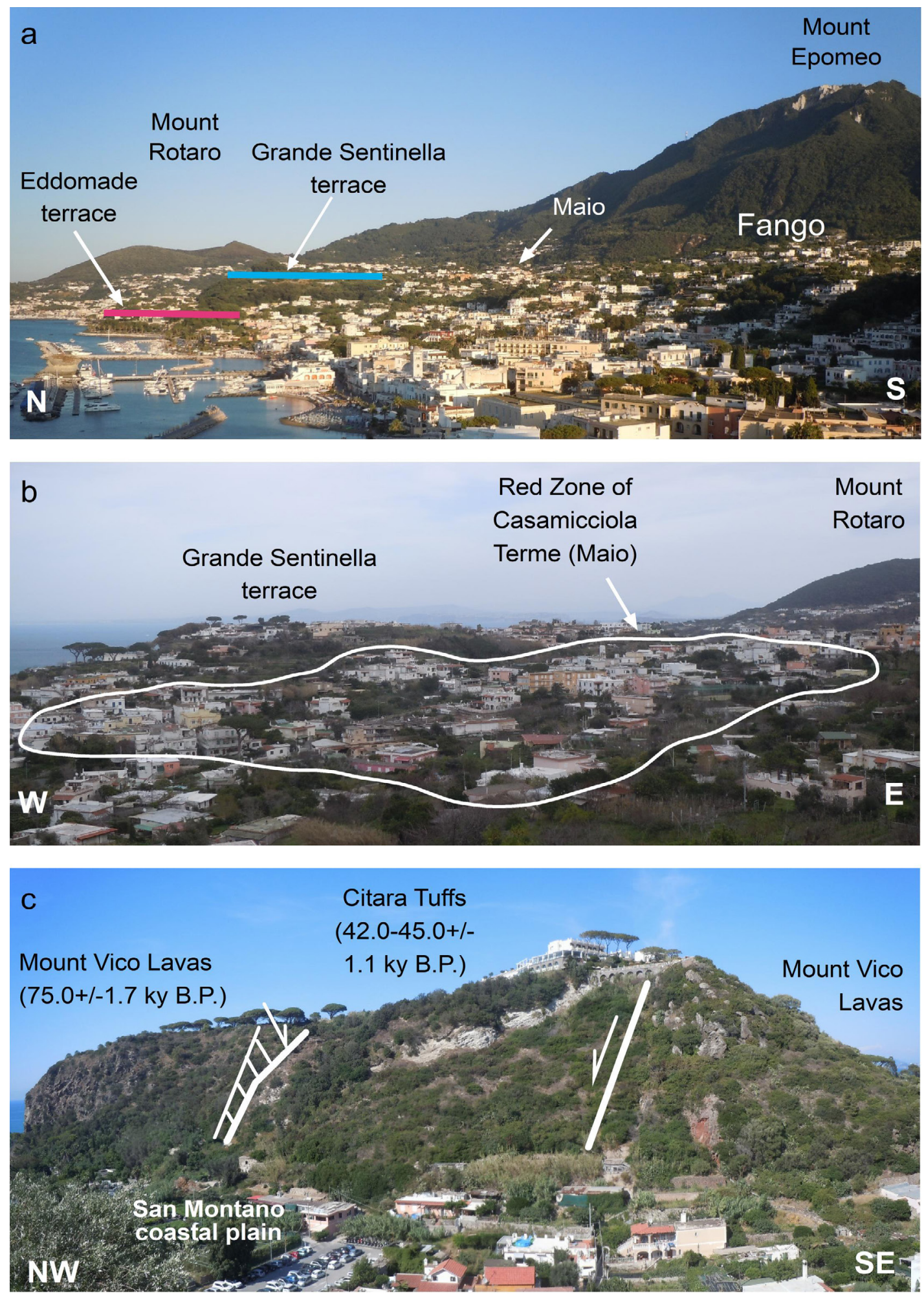

Fig. 2 - Main morphological and structural features of the Ischia Island: a) panoramic view of the northern side of the island, from Mount Epomeo (787 m a.s.l.) to the Tyrrhenian Sea coast. Maio and Fango the most damaged neighborhoods of Casamicciola Terme and Lacco Ameno are shown, which lay on the lower slope of Mt Epomeo and are at the limit of a very densely inhabited and urbanized area. The recent geomorphic evolution of the island is testified in the coastal belt by remnants of the Holocene Grande Sentinella and Eddomade terraces, at about 120 and $30 \mathrm{~m}$ a.s.l. respectively and bounded seaward by steep cliffs, and by the Mount Rotaro Volcanic Complex (upper Holocene), in the background. b) View from south of the Red Zone of Casamicciola Terme (Maio), located in a West-East trending morphological depression at the rear of the Grande Sentinella terrace. c) View of the Mount Vico promontory showing adjoining up- and down-thrown blocks, with the outcropping Mount Vico Lavas and Citara Tuffs (SBRAna \& TocCACELI, 2011; K/Ar radiometric age dates from: Gillot et alii, 1982; Poli et alii, 1987) respectively, separated by SW-NE trending, high angle, normal faults, probably re-activating older caldera-related structures. This structural pattern, with sub-vertical normal faults separating "horst and graben like" blocks, is recurrent throughout the northern and western flanks of the island. 
The post-caldera volcano-sedimentary sequence, the thickness of which was reconstructed by outcrop measurements and borehole data (VEzzoli, 1988; SBRANA \& TocCACELI, 2011), was accommodated in a rapidly subsiding intra-caldera basin (60-33 ky) and partly in concomitance with the eustatic sea-level rise and stillstand of the Marine Isotope Stage 3 (MIS 3; BENJAmin et alii, 2017) until the inception of the Mount Epomeo resurgence. The fast accumulation and burial of tuffs and marine sediments should have likely caused the strong over-consolidation and strengthening of mechanical properties of these deposits.

The fast and impressive resurgence of Mount Epomeo in the last 33 ky (TIBALDI \& VEzzoli, 1998; 2004), concomitant with active faulting and explosive events, exposed the ignimbrites and the overlying marine sediments to subaerial slope instabilities, from which debris avalanches, debris flow and lahars developed (Del Prete \& Mele, 1999; 2006; Della Seta et alii, 2015). Covers as thick as $150 \mathrm{~m}$ of gravel-sand sized epiclastites and landslide deposits are widespread from the flanks of Mount Epomeo down to the coast. These deposits, which comprise the Punta del Soccorso, Lacco Ameno and Grande Sentinella units (SBRANA \& TocCACELI, 2011), are locally interbedded with ashy and pumiceous tuffs, scoria cones, lavas, coastal and alluvial sediments.

The resurgent block of Mt Epomeo is bounded almost concentrically by sub-vertical normal faults, some of them being still active nowadays. In particular on the northern flank of Mount Epomeo, W-E and WNW-ESE trending faults border narrow "horst and graben" like structures. These structures are well evident in the Casamicciola Terme area (the Red Zone of Figs 1 and 2; see also Tibaldi \& Vezzoli, 1998), as emphasized by the trellis like pattern of the local hydrographic network, or are buried below landslide deposits, such as at Fango southward of Lacco Ameno. These W-E trending graben-like basins may have originated either by the N-S directed extension related to the resurgence of Mount Epomeo (NAPPI et alii, 2021; with references), or by the reactivation of the bounding normal faults in a strike-slip motion (left- lateral), as suggested by the solution of focal mechanisms of the 2017 event (Fig. 1d).

In the late Upper Pleistocene-Holocene a set of coastal faults, both parallel and radial with respect to the coastline, was activated, in concomitance with the uplift of marine terraces and the most recent volcanism: Mount Rotaro, Zaro plateau and Fundera dome (Vezzoli et alii, 2009; Fig. 3).

\section{THE GEO-LITHOLOGICAL MAP AND THE MAP OF INVESTIGATIONS}

The integrated approach necessary for SM studies implies iterative and interactive elaborations of geological, geophysical and geotechnical data (GRUPPO DI LAVORO MS, 2008). As a result of this approach, a set of thematic maps, at scales 1:3.500 or 1:5.000, was produced by the private consultants in charge of the different municipalities (Oliviero et alii, 2019; Riello et alii, 2019; Toscano et alii, 2019). After field surveys and data collection from past and new campaigns of geophysical and geotechnical investigations, a geo-lithological map, a map of the investigations and a map of Seismically Homogeneous Microzones were drawn for each municipality.
Those maps were then homogenized by the support team to obtain comprehensive, wide-area maps covering all the northern and western side of the Ischia Island. In particular, the whole amount of data was quality checked, and collected in an SQLite/SpatiaLite geodatabase using a QGIS open source software.

The complex stratigraphic and tectonic setting of the island, with the associated volcano-tectonic morphologies, have been reconstructed based on previous geological studies integrated with new investigation and geological surveys. The new geological observations dealt with the origin of the exposed lithotypes and faults confirming, for the first, the widespread presence of epiclastic deposits on outcrop and, for the second ones, the presence of highangle to subvertical normal faults with dominant dipslip cinematics. The results of these surveys have been summarized into the wide-area geo-lithological map of figure 4. Lithotypes were represented on the map according to the basic units encoding suggested by Commissione TECNICA PER LA MICROZONAZIONE SISMICA (2020). Details of the local lithotypes and related codes are reported in table 1 , distinguishing bedrock from cover soil units.

Examples of outcrops of the geo-lithological units are shown in figure 5 with the best exposed lithotypes correlated to the lithostratigraphic units currently on use (SBRANA \& Toccaceli, 2011). In the supplementary materials, table $\mathrm{S} 1$ reports the scheme of correlation among lithostratigraphic and geo-lithological units, with the formers deriving from the very detailed geological maps at scale 1:10.000 by Vezzoli (1988) and SBrana \& Toccaceli (2011). The criteria used for correlation are based on similarity of lithology among lithostratigraphic and geo-lithological units, age and depositional processes.

Summarizing, the bedrock is composed by the basal lavas, and by overlying multi-layered succession from the Monte Epomeo Green Tuff, to submarine epiclastic sands (tuffite) and clays, the Citara Tuff and younger lavas, such as the Zaro and Fundera Lavas. Soil cover units are represented by younger sub-aerial pyroclastites, widespread epiclastites re-sedimented from the older volcanites, ancient landslides (mostly debris flow and avalanches), and coastal-alluvial plain deposit.

The mapping of landslides derives from the IFFI (inventory of landslides of Italy) database for the Campania Region (available at http://www.difesa.suolo.regione. campania.it/content/view/64/28/ website on 31/05/2021).

The localization of previous and new geophysical and geotechnical investigations is reported on the wide area map of figure 6 .

Coupling the results of the geological studies and of new geophysical and geotechnical investigations it has been possible to draw the geo-lithological cross sections shown on figure 7. All the sections run from the peak of Mount Epomeo to the coast, crossing the main faults recognized on the literature and thus showing the main tectono-stratigraphic features of the investigated sectors of the island (VEzzoli, 1988; Tibaldi \& Vezzoli, 1998). In the a-a' (Lacco Ameno) and b-b' (Casamicciola Terme) sections the stratigraphic marker SFCO is recognized, which corresponds to the silty-clayey marine sediments (Cava Leccie unit) overlying the Mount Epomeo Green Tuff ignimbrite and the marine epiclastite or tuffite (SFGRS lithotype); its dislocations highlight the graben structures along the sections in the Piazza Maio (bb') and Fango (a-a') localities. 


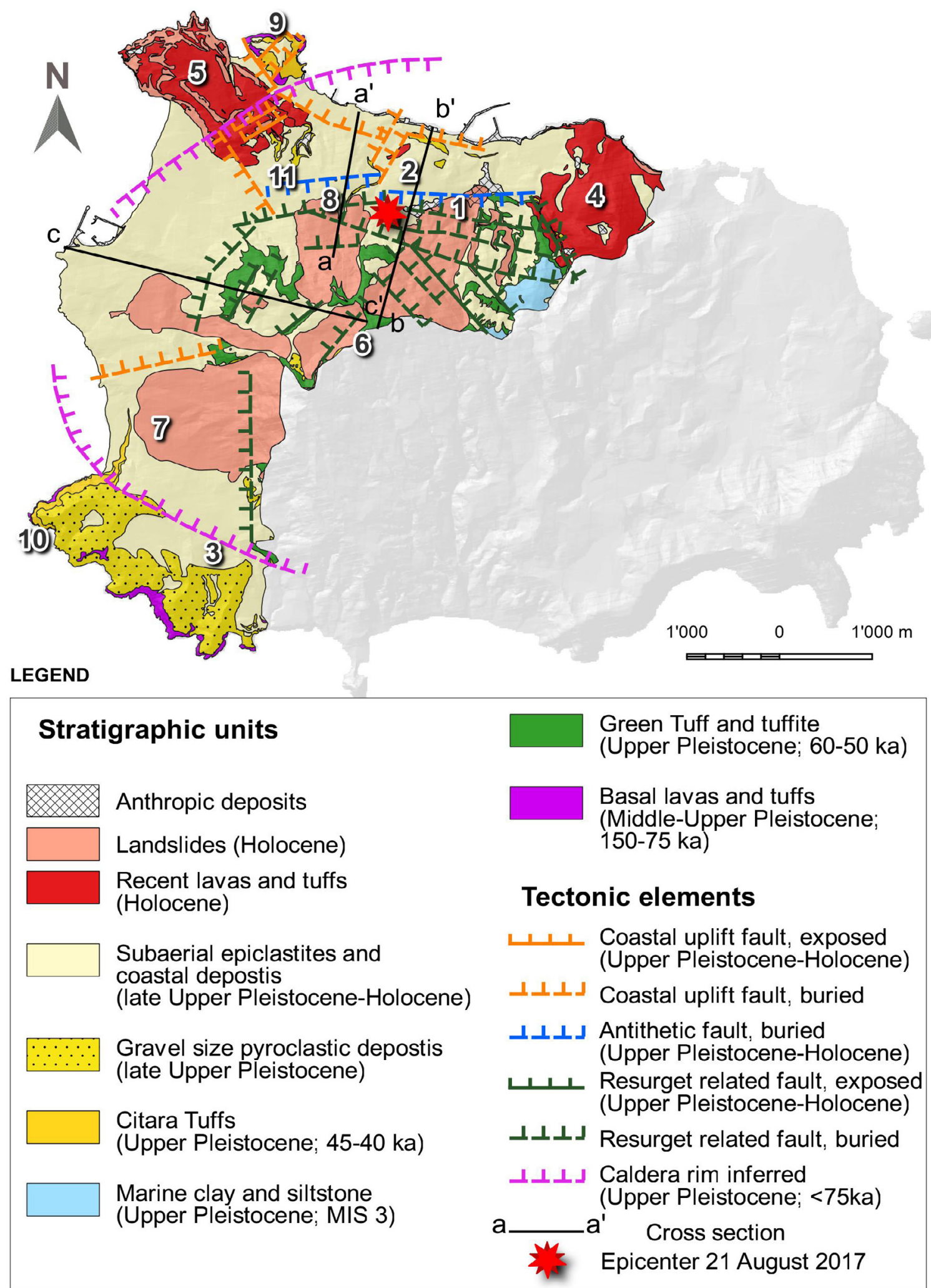

Fig. 3 - Structural sketch map of the northern and western Island of Ischia. The topographic relief is based on a $20 \times 20 \mathrm{~m}$ resolution DEM. The featured stratigraphic units are simplified from the geological map of SBRANA \& TOCCACELI (2011), and are reported with their age. Structural features, essentially normal faults, are based on the integration and partial modification of data from Vezzoli (1988), Tibaldi \& Vezzoli $(1998 ; 2004)$ and SBrana \& TOCCACELI (2011). Four sets of faults, exposed and buried, are distinguished with different colors and on the basis of their chronology; the oldest set refers to the caldera collapse. Numbers refer to the localities cited in the text, and the cross sections are represented on figures 4 and 7. List of localities: 1) Piazza Maio; 2) Grande SentinellaFundera; 3) Panza; 4) Mount Rotaro; 5) Zaro plateau; 6) Mount Epomeo; 7) Citara; 8) Fango; 9) Mount Vico; 10) Punta Imperatore; 11) Mezzavia. 


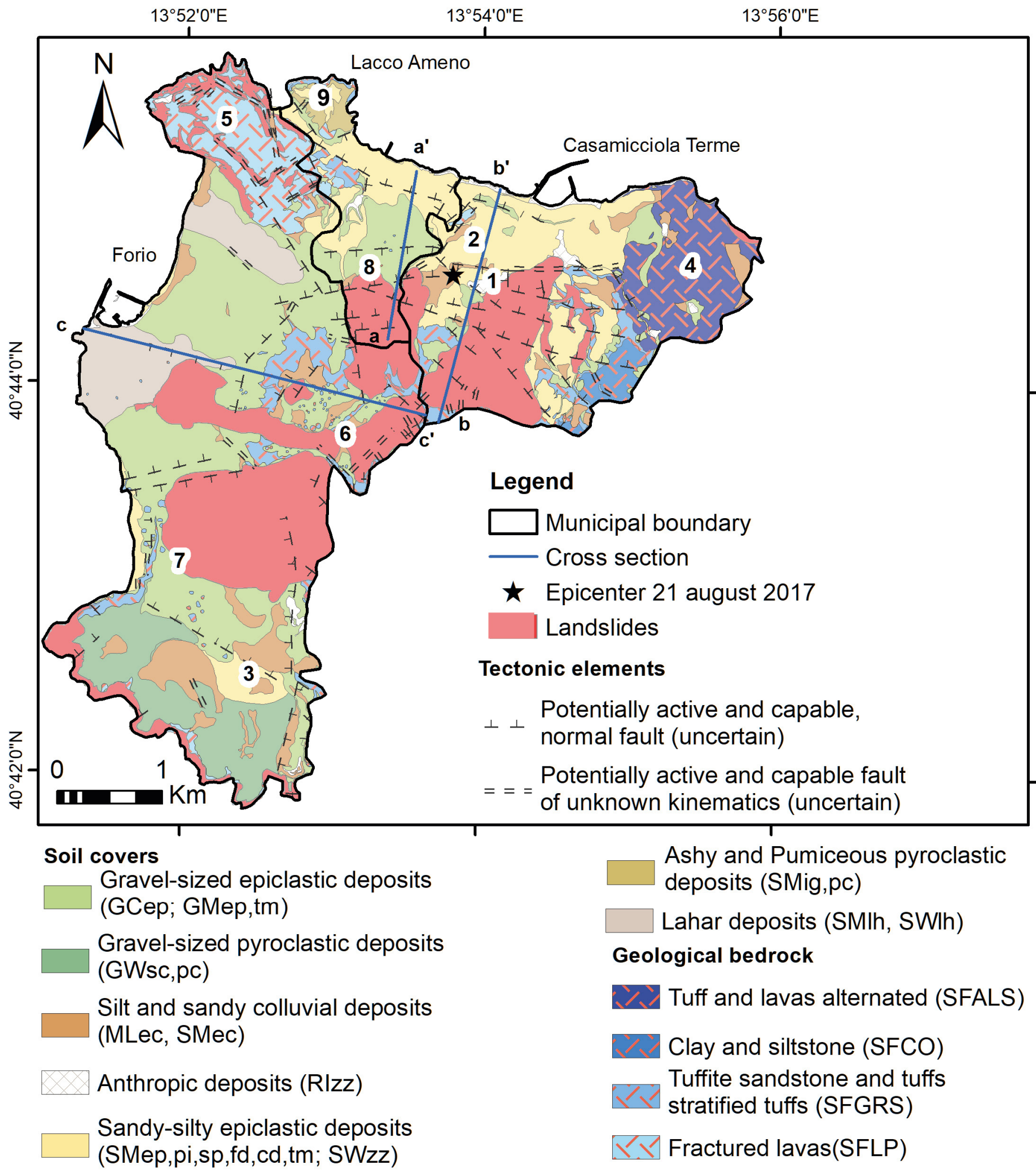

Fig. 4 - Geo-lithological map of the northern and western Island of Ischia. Mapped geo-lithological units are composed of lithotypes' assemblages referred to the cover soil and geological bedrock. Codes of lithotypes are based on COMMISSIONE TECNICA PER LA MICROZONAZIONE SISMICA (2020); See also Table 1 for details on the lithotypes' characters. Numbers refer to the localities cited in the text and cross sections are represented on figure 7. List of localities: 1) Piazza Maio; 2) Grande Sentinella; 3) Panza; 4) Mount Rotaro; 5) Zaro plateau; 6) Mount Epomeo; 7) Citara; 8) Fango; 9) Mount Vico. 
TABLE 1

List of the cover soil and bedrock lithotypes, units of the geo-lithological map of figure 4: (1) codes and Italian names are from COMMISSIONE TECNICA PER LA MICROZONAZIONE SISMICA (2020).

\begin{abstract}
Cover soil lithotypes (1)
RIzz (Terreni contenenti resti di attività antropica): Anthropogenic deposits

CLpl (argille inorganiche di medio-bassa plasticità di ambiente di stagno costiero): Coastal pond, inorganic clay with medium-low plasticity (only found in the subsoil)
\end{abstract}

MLec (eluvi/colluvi composti da limi inorganici di bassa plasticità): Eluvial/colluvial, inorganic silt with low plasticity

SM-SWlh (sabbie limose e sabbie con ghiaia deposte da colate tipo lahar): Silty and gravelly sand from lahar flows

SMpc (piroclastiti: cineriti, lapilli e pomici): Ashes with small lapilli and pumices

SMep (sabbie epiclastiche): Talus, epiclastic sand

SMcd-fd (sabbie limose di conoide e falda detritica): Talus, silty sand

SMec (eluvi/colluvi composti sabbie limose): Eluvial-colluvial silty sand

SMpi (sabbie limose di piana alluvionale e costiera ): Alluvial and coastal plain silty sand

Bedrock lithotypes (1)

SFALS (alternanza di litotipi, stratificato, fratturato alterato) Multilayered and alternating, fractured/altered rocks (interbedded lavas and pyroclastites)

SFLP (substrato lapideo, fratturato/alterato): Fractured and altered bedrock (lavas)

The SFLP unit, which corresponds to the Fundera Lavas (SBRAna \& Toccaceli, 2011) in the Grande Sentinella area (Casamicciola municipality), is detected only in b-b' section. Its occurrence in the subsoil is revealed by deep boreholes and confirmed by seismic noise measurements. Both the a-a' and b-b' sections put in evidence the important tectonic control on the stratigraphy of the norther flank of Mount Epomeo, the uplift of which triggered massive landslides events in sub-aerial setting: wide debris avalanche deposits are indeed characteristics elements of this sector, which are identified by the SMep, GMep, GCep lithotypes correlated with the Lacco Ameno and Grande Sentinella units (SBRAna \& TocCACELI, 2011).

The section c-c' drawn along the W-E direction within the Forio municipality shows a different stratigraphical and structural setting, with a simple multilayered tabular structure at the base of Mount Epomeo. Here, in fact, the geological bedrock is represented by the Green Tuff and the Citara Tuff (SFGRS lithotype), which is overlain by buried nearshore sands (SMsp lithotype) and by exposed debris avalanche (GMep) and lahar (SMlh)
SMtm (sabbie limose di terrazzo costiero): Coastal terrace silty sand

SMsp (sabbie limose di spiaggia emersa e sommersa): Shoreface and beachface silty sand

SWzz (sabbie ghiaiose di ambiente indefinito): Gravelly sand of undefined environment (only found in the subsoil)

GWpc (piroclastiti grossolane: lapilli e pomici con matrice cineritica) Lapilli-sized piroclastites, pumices with ashy matrix

GWsc (scorie laviche più o meno saldate): welded scorias

GMep (ghiaie sabbioso-limose, epiclastiche): Epiclastic sandy-silty gravel from scree cones, talus and minor alluvial fans

GCep (ghiaie a matrice argillosa-sabbiosa, epiclastiche): Epiclastic clayey-sandy gravel from talus

GMtm (ghiaie sabbioso-limose di terrazzo costiero): Coastal terrace sandy-silty gravel
SFCO (substrato coesivo sovraconsolidato, fratturato/alterato): Cohesive, overconsolidated, fractured/altered bedrock (marine siltstone and claystone)

SFGRS (substrato granulare, cementato/saldato, stratificato fratturato/ alterato): Granular, bedded, cemented or welded, fractured/altered bedrock (ignimbrites, welded tuffs, epiclastic sandstone) deposits, with the latter two being correlated with the Punta del Soccorso unit (SBRana \& Toccaceli, 2011). The Forio lowland is downthrown to the west by N-S and NE-SW trending normal faults, flanking the Mount Epomeo, and by a buried, NW-SE trending normal fault that bounds westward the Fango-Mezzavia area (see also figures 3, 4 and 7).

\section{GEOPHYSICAL AND GEOTECHNICAL SITE CHARACTERIZATION}

In the area of interest a great number of data was collected from previous studies and further investigations were conducted by the private consultants to integrate the available database (MANCINI et alii, 2019; Oliviero et alii, 2019; RiEllo et alii, 2019; Toscano et alii, 2019): 84 seismic noise measurements, processed in terms of HVSR spectral ratios, and 34 surface waves tests (MASW) were carried out. Moreover, four boreholes were drilled for the execution of Down-Hole tests (35 to 

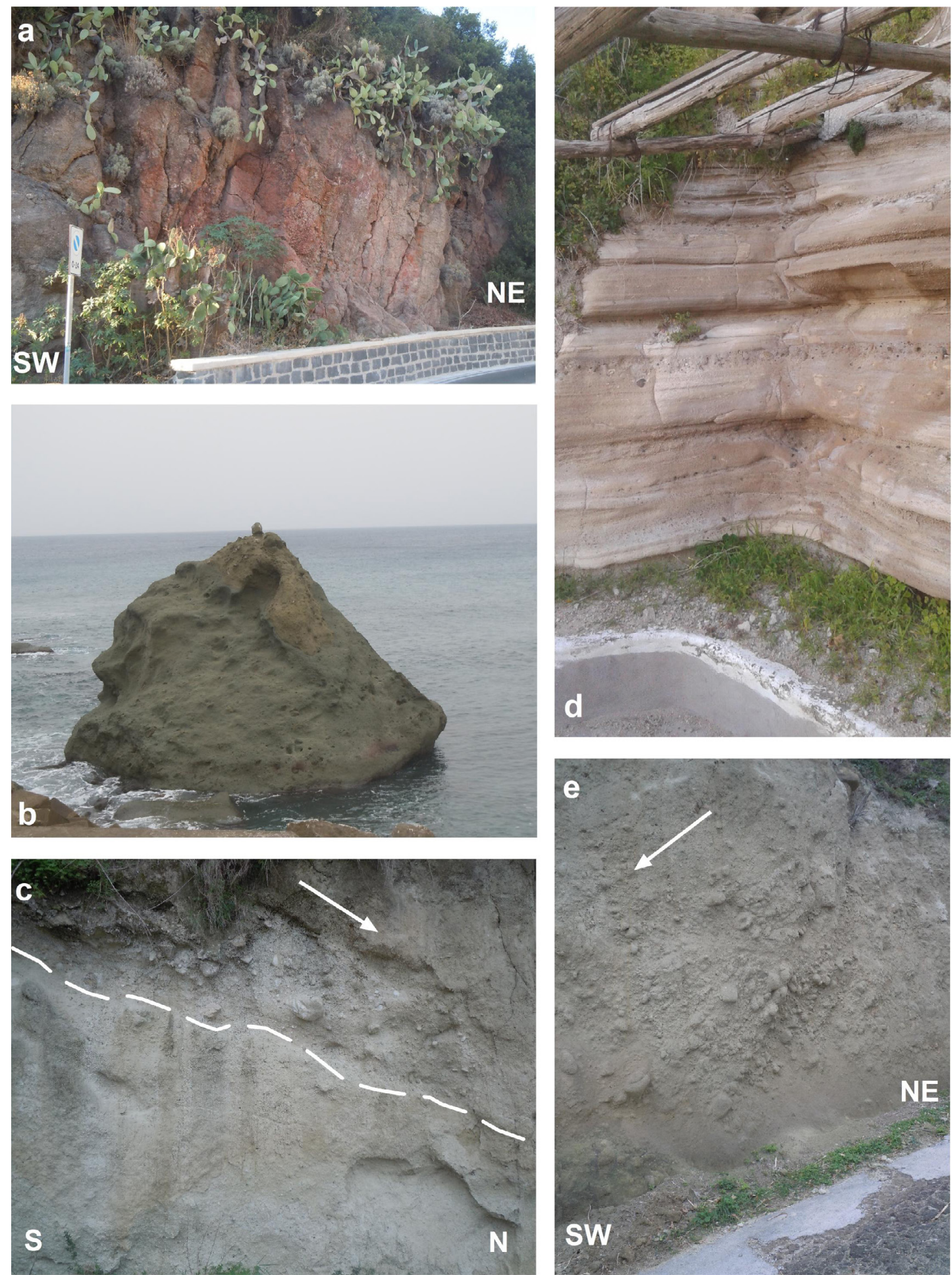

Fig. 5 - Examples of bedrock (a-d) and cover rock (c and e) units. Lithostratigraphic names and codes are from SBRANA \& Toccaceli (2011); geo-lithological names and codes are from CoMmissione TECNICA PER LA MICROZONAZIONE SISMICA (2020). a) Outcrop of Mount Vico trachitic Lavas, San Montano lithofacies $\left(\mathrm{LMV}_{\mathrm{b}}\right.$ ) close to Piazza Santa Restituta (Lacco Ameno), corresponding to the SFLP lithotype "Substrato geologico lapideo fratturato/alterato" (fractured/altered geological bedrock). b) Block of the Tufo verde del Monte Epomeo (TME) at Forio, Ar/Ar date $56.5 \pm 3.0 \mathrm{ky}$ B.P. (DeIno A. in SBRAna \& Toccaceli, 2011). The Tufo verde corresponds to the SFGRS lithotype "Substrato geologico granulare cementato, stratificato fratturato/alterato" (fractured/altered, cemented or welded, granular, bedded bedrock). c) Sub-marine epiclastic sandstone of the Campomanno unit (CPM; upper Pleistocene) overlain by matrix-supported sandy gravels of the Holocene Grande Sentinella unit (GSN Holocene), above the dashed line, here interpreted as a sub-aerial debris flow deposit. The white arrow shows the dipping bed and paleoflow directions (Santa Barbara, Casamicciola Terme). The Campomanno unit corresponds to the SFGRS lithotype; the Grande Sentinella unit corresponds to the GMep lithotype "depositi epiclastici composti da ghiaie limose, miscela di ghiaia, sabbia e limo" (epiclastic silty gravel and mixed gravel, sand and silt). d) Planar bedded Citara Tuffs (TCT), with alternated lapilli- and ash-sized clasts, interpreted as sub-aerial pyroclastic fall and surge deposits (Citara cliff, Forio). The Citara Tuff are correlated to the SFGRS lithotype. e) Outcrop of matrix-supported sandy-silty gravel of the Punta del Soccorso unit (PUS; upper Pleistocene-Holocene) at Forio Porto. The white arrow shows the dipping bed and paleo-flow direction, as it is highlighted by aligned pebbles and cobbles of reworked Tufo verde; this outcrop is interpreted as a lahar deposit after Della SeTa et alii (2015). The Punta del Soccorso unit corresponds to the SMlh lithotype "sabbie ghiaiose da lahar" (lahar gravelly sand). 


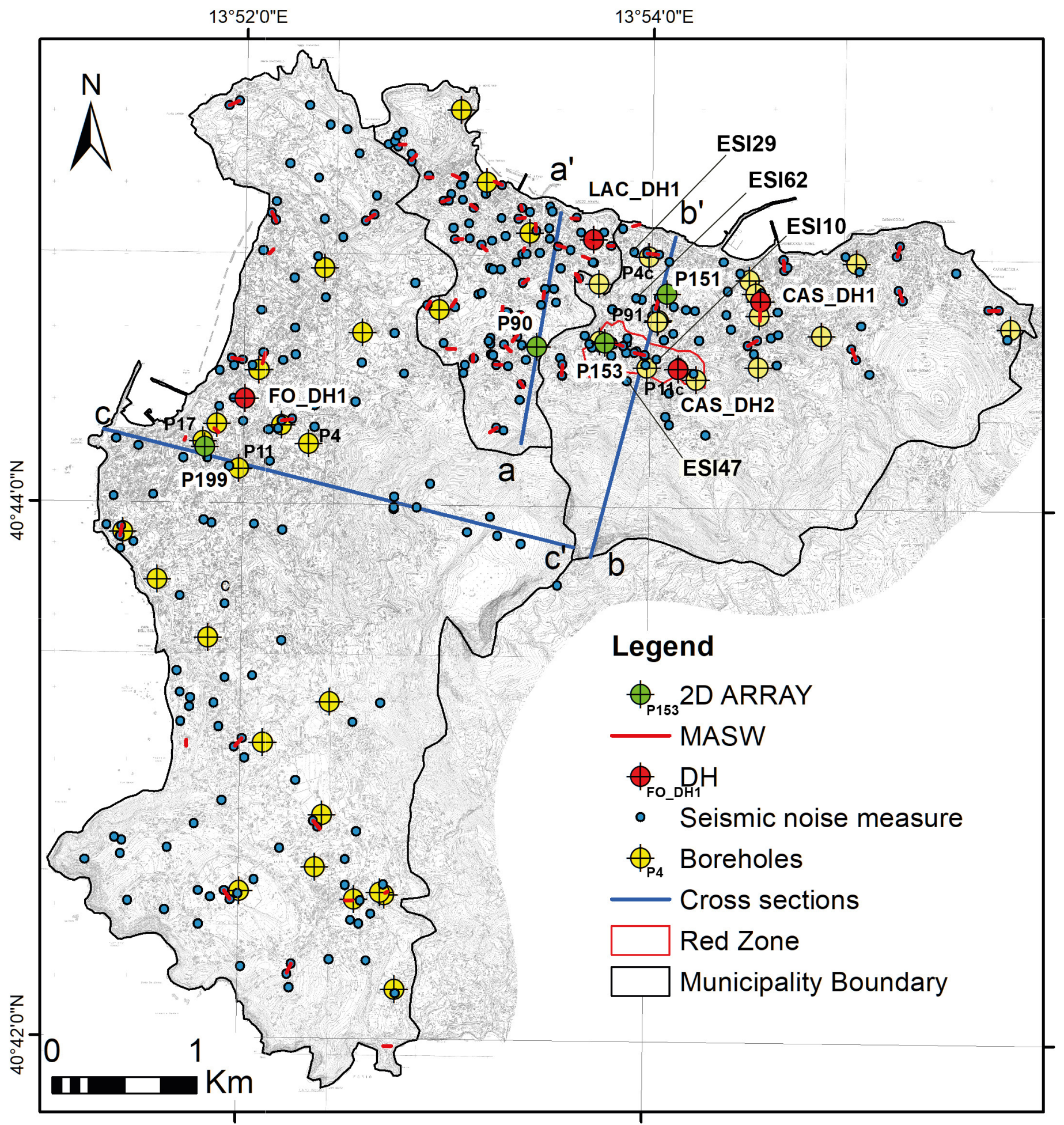

Fig. 6 - Map of investigations. The map derives from the collection of data from each municipality (OliveIro et alii, 2019; RIELLo et alii, 2019; Toscano et alii, 2019). Selected investigations (i.e., boreholes with down hole test, noise measurements and seismic arrays) are reported with their own code and refer to figures 8-10. Cross sections refer to figure 7 .

$50 \mathrm{~m}$ deep) which permitted to retrieve 13 undisturbed soil samples for laboratory testing (Fig. 8). The boreholes were drilled mostly across coarse grained soils with shear and compression wave velocities increasing with depth, except for that located at Lacco Ameno, which intercepted a relatively soft clayey deposit $(\mathrm{CLpl})$ characterized by a velocity inversion. Even when a bedrock lithotype was intercepted, its shear wave velocity $\mathrm{V}_{\mathrm{s}}$ resulted lower than $800 \mathrm{~m} / \mathrm{s}$, due to its degree of weathering and/or fracturing. 


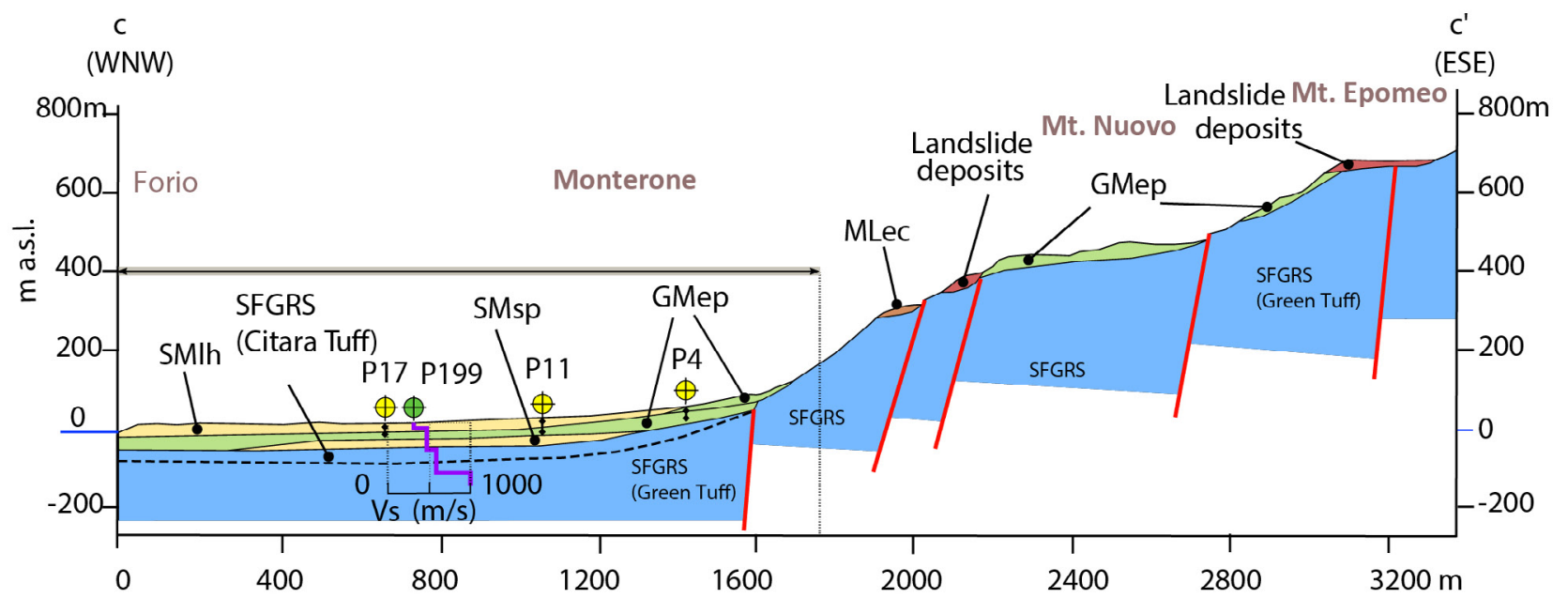

b

b'

(SSW)

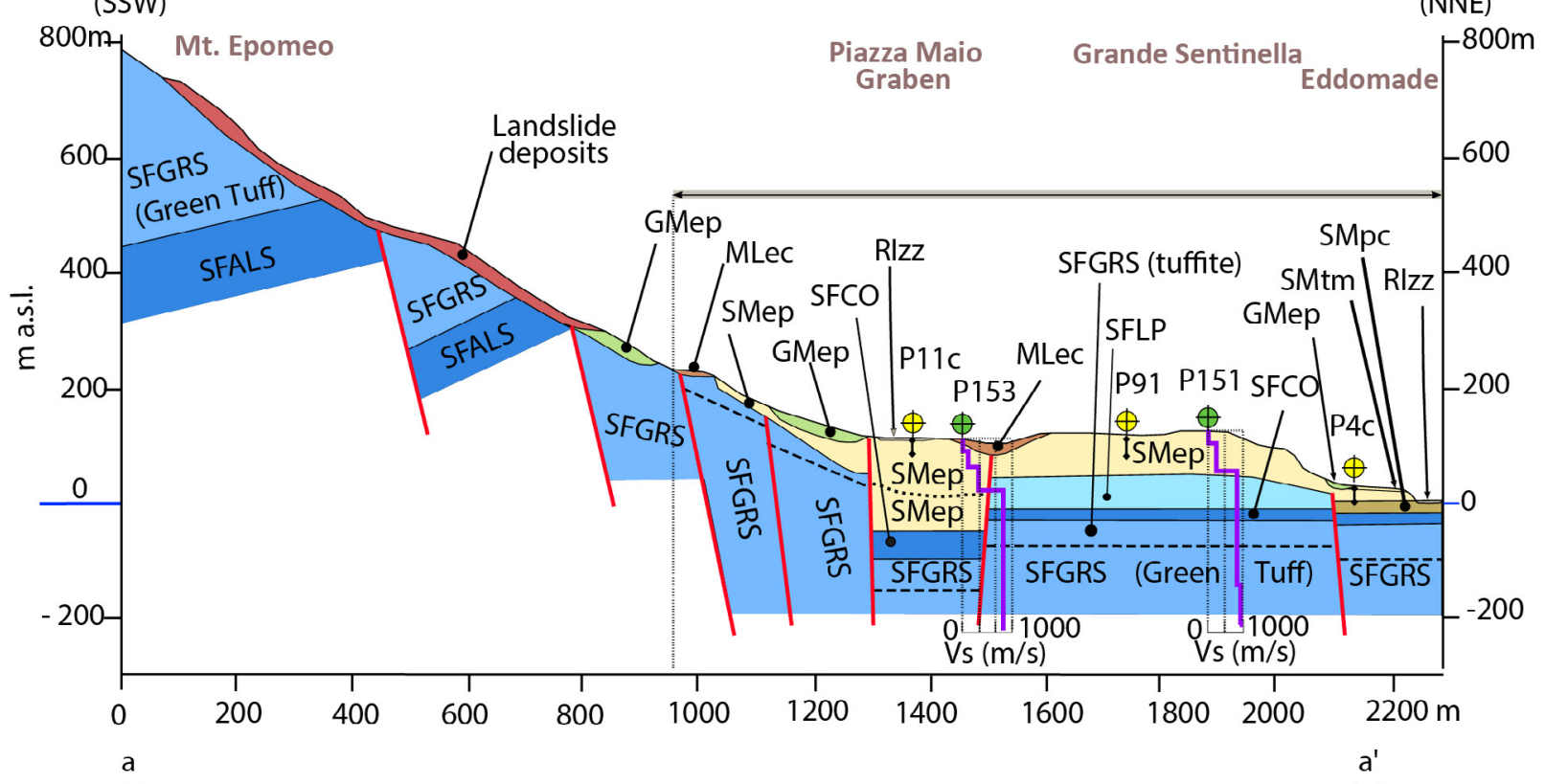

(S)

(N)

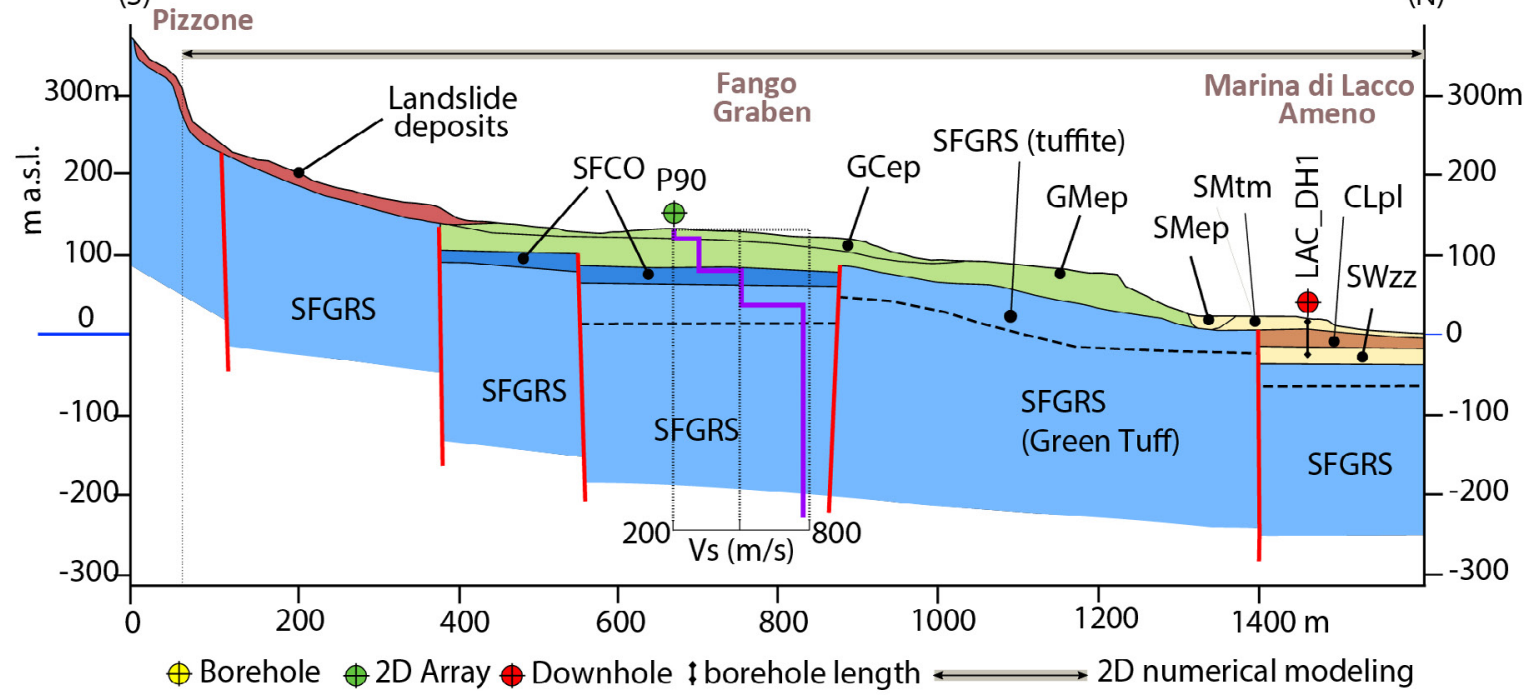

Fig. 7 - Geo-lithological cross sections. The traces of sections are reported on maps of figures 3, 4 and 6 . Codes of geo-lithological units, lithotypes, refer to table 1, while selected investigations are crossed by or projected on the sections (see also figure 6 ). The shear wave $\mathrm{V}_{\mathrm{s}}$ profiles from 2D seismic arrays and the tracts investigated by 2D numerical modelling are also reported on the sections (see also figures 10 and 15-17). 

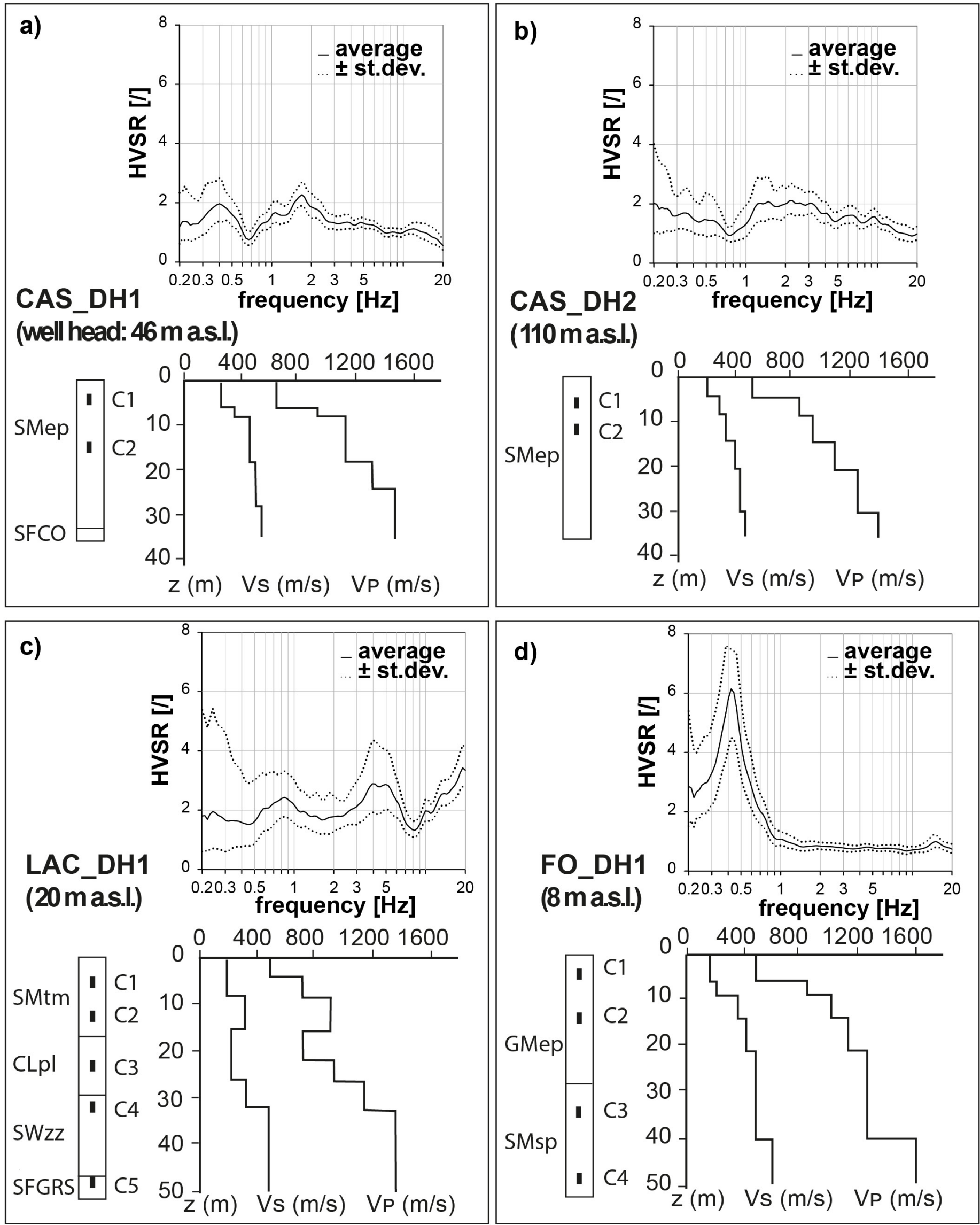

Fig. 8 - Dilled boreholes with position of the samples (C1 to C5) retrieved for geotechnical tests (see also fig-ure 11 ) and results of down hole test investigations: $\mathrm{V}_{\mathrm{p}}$ longitudinal and $\mathrm{V}_{\mathrm{s}}$ shear waves' velocity pro-files. Lithotypes' codes refer to table 1 . For each borehole a related HVSR spectrum from noise measurements is reported. 


\section{SURFACE GEOPHYSICAL INVESTIGATIONS}

Many seismic noise measurements processed by means of HVSR technique show a quite stable low frequency peak $\left(\mathrm{f}_{0}<1 \mathrm{~Hz}\right)$ in many sectors of the investigated area despite the high variability in the shallow geological units expected in this complex volcanic setting. Figure 9 shows some representative examples of spectral ratios from noise measurements located as reported on figure 6 .

The observation of low frequency peak has suggested the presence of a deep impedance contrast, which needed further investigation using high aperture 2D seismic arrays. Thus, 11 passive $2 \mathrm{D}$ arrays were installed by the support team to obtain deep vertical $V_{s}$ profiles trough non-linear inversion of Rayleigh waves dispersion and ellipticity curves. This approach integrated the information derived by MASW and DH data, extending the investigation depth down to some hundreds of meters.

The array data were based on stand-alone seismic stations equipped with high resolution 3 channels Reftek 130 data logger connected to a three-component velocity sensor Lennartz LE-3d $5 \mathrm{~s}$. The selected sensor can properly operate in the $0.2-40 \mathrm{~Hz}$ frequency range and are suitable to record with a good resolution the ambient noise wavefield, characterized by resonances at low frequency (less than $1.0 \mathrm{~Hz}$ ) as shown, for instance, by the HVSR results of figure 9 . The number of deployed stations varied from 12 to 15, with an array aperture between 100 and $300 \mathrm{~m}$ according to the logistics of the investigated sites. The accuracy of sensors positioning
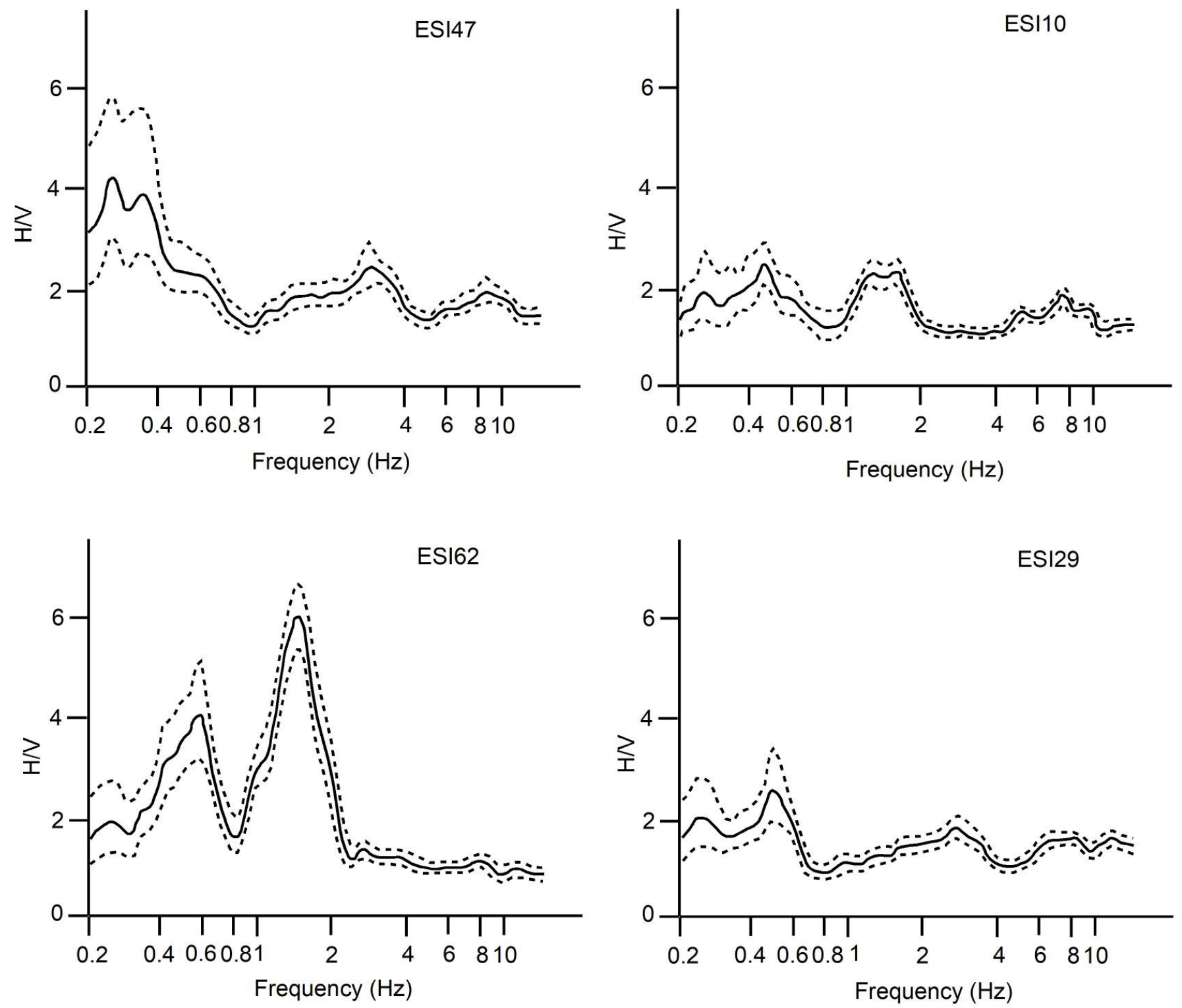

Fig. 9 - Selected HVSR spectra from ambient noise measurements (see figure 6 for their location): continuous black line indicates the geometric mean; dotted lines are the $\pm \sigma$ standard deviation. A low frequency $\left(\mathrm{f}_{0}<1.0 \mathrm{~Hz}\right)$ amplitude peak of fundamental frequency $\mathrm{f}_{0}$ is recurrent in all the cases, as it is commonly found throughout the island. 
was obtained using a GNSS Leica positioning system that allows to obtain sensors coordinates with an error of few centimeters. Signals were continuously recorded at 250 samples per second during an at least 2 hours long time window.

At all the tested sites, HVSR were first evaluated to verify the homogeneity in the site response and to obtain the resonance frequency in the investigated area. Then the Rayleigh wave dispersion curve was calculated at the array using both FK and ESAC approaches. A joint inversion of dispersion curve and HVSR ellipticity curve was performed to obtain the velocity profile at the investigated sites. The inversion results were mainly controlled by the HVSR data in the low frequency range $(<2 \mathrm{~Hz})$ and by dispersion curves for higher frequencies. Due to the array configuration, the resolution for the shallowest layers of the investigated subsoil volume was not as high as that obtained by the conventional 1D MASW and DH tests.

Shear wave velocity $\mathrm{V}_{\mathrm{s}}$ profiles resulting from four selected arrays, located along the a-a', b-b' and c-c' cross sections, are reported as examples in figure 10. The shear wave profiles confirm that bedrock is located at a depth often exceeding $100 \mathrm{~m}$ from surface, as already expected from the results of HVSR, and added fundamental information on the trend of $\mathrm{V}_{\mathrm{s}}$ values in deeper soil layers not reached by boreholes.

\section{LABORATORY INVESTIGATIONS}

Laboratory tests were carried out at the University of Napoli on 10 samples retrieved along the 4 boreholes to measure the physical and state properties of the sampled soil deposits, as well as to characterize their non-linear and dissipative behaviour by means of Cyclic Torsional Shear (CTS) tests with the THOR cell (D'ONOFRIO et alii, 1999). The soil samples are mainly constituted by silty sand and sandy silt. Due to the ashy nature of fine particles, only samples characterised by a fine content $(\mathrm{d}<0.06 \mathrm{~mm})$ exceeding $50 \%$ and a clay fraction higher than $20 \%$ exhibited non-negligible plasticity.

Ten cyclic torsional shear tests were carried out on as many undisturbed samples. The tests results are shown in figure 11 in terms of data points showing the variation with cyclic shear strain amplitude, $\gamma$, of the normalized stiffness, $G / G_{0}$, and of the hysteretic damping ratio, D. In figure 11, the open squares refer to non-plastic samples, while the full circles identify the plastic ones. The decay of the shear modulus with shear strain is generally less pronounced for plastic soil samples rather than for nonplastic ones. An exception is represented by the samples of debris material (asterisks in figure 11), characterized by a non-negligible gravel fraction, that seems to influence more significantly the decay of shear modulus with respect to soil plasticity (Fig. 11a). This latter seems to affect significantly even the dissipative behaviour of the tested soils, being the small strain damping ratio of soil samples with plastic fine content higher than that measured on non-plastic samples, although these latter show a more pronounced increase at higher strain levels (Fig. 11b).

The peculiar non-linear and dissipative behaviour of these volcanic materials, of pyroclastic origin, could not be interpreted using the standard curves usually adopted for soils with similar grain size distributions, such as those suggested by SEED \& IDRISs (1970) for granular soils and by VucETIC \& DoBRy (1991) for finegrained soils (see Figure $11 \mathrm{a}-\mathrm{b}$ ). As a matter of fact, the pyroclastic/epiclastic soil with non-plastic fine fraction is characterized by a more pronounced linear behaviour if compared with that predicted by SEED \& IDRISs (1970) for quartz sand, due to both the high percentage of fine fraction and considerable interlocking of pyroclastic soil grains. On the other hand, the volcanic samples with plastic fine are characterized by a wider range of linear behaviour, but also by a sharper reduction of shear modulus at increasing strain level, if compared to the curves by Vucetic \& DoBRy (1991) for plastic soils. For this
P153

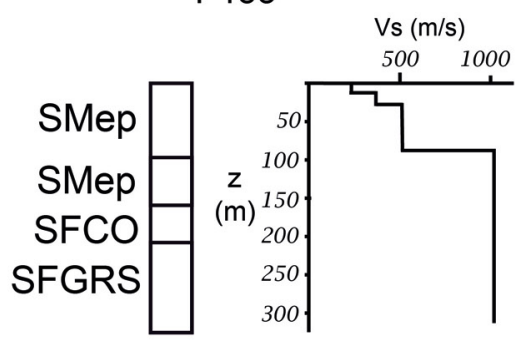

P151

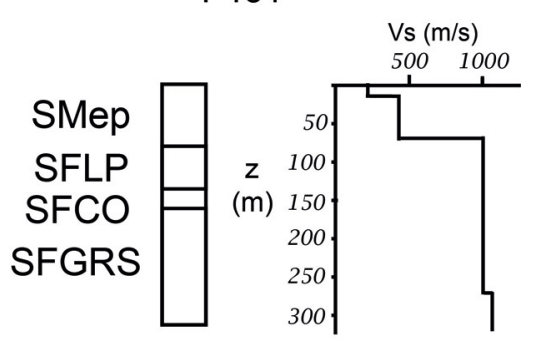

P90

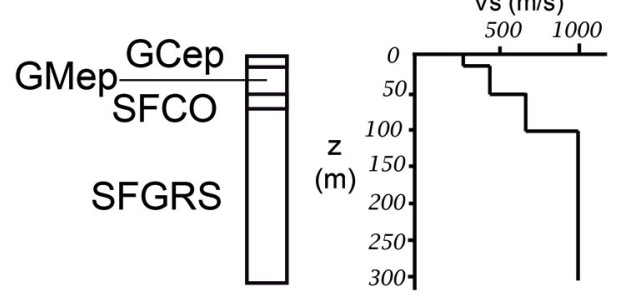

P199

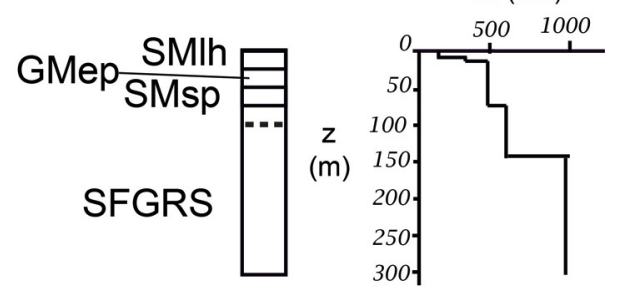

Fig. 10 - Best-fit models of $\mathrm{V}_{\mathrm{s}}$ shear waves' velocity profiles from selected 2D seismic arrays (see figure 6 for their location). The stratigraphy of associated logs derives either directly from borehole data close to the site of investigation (P151, P199) or indirectly from stratigraphic correlation (P153, P90). 


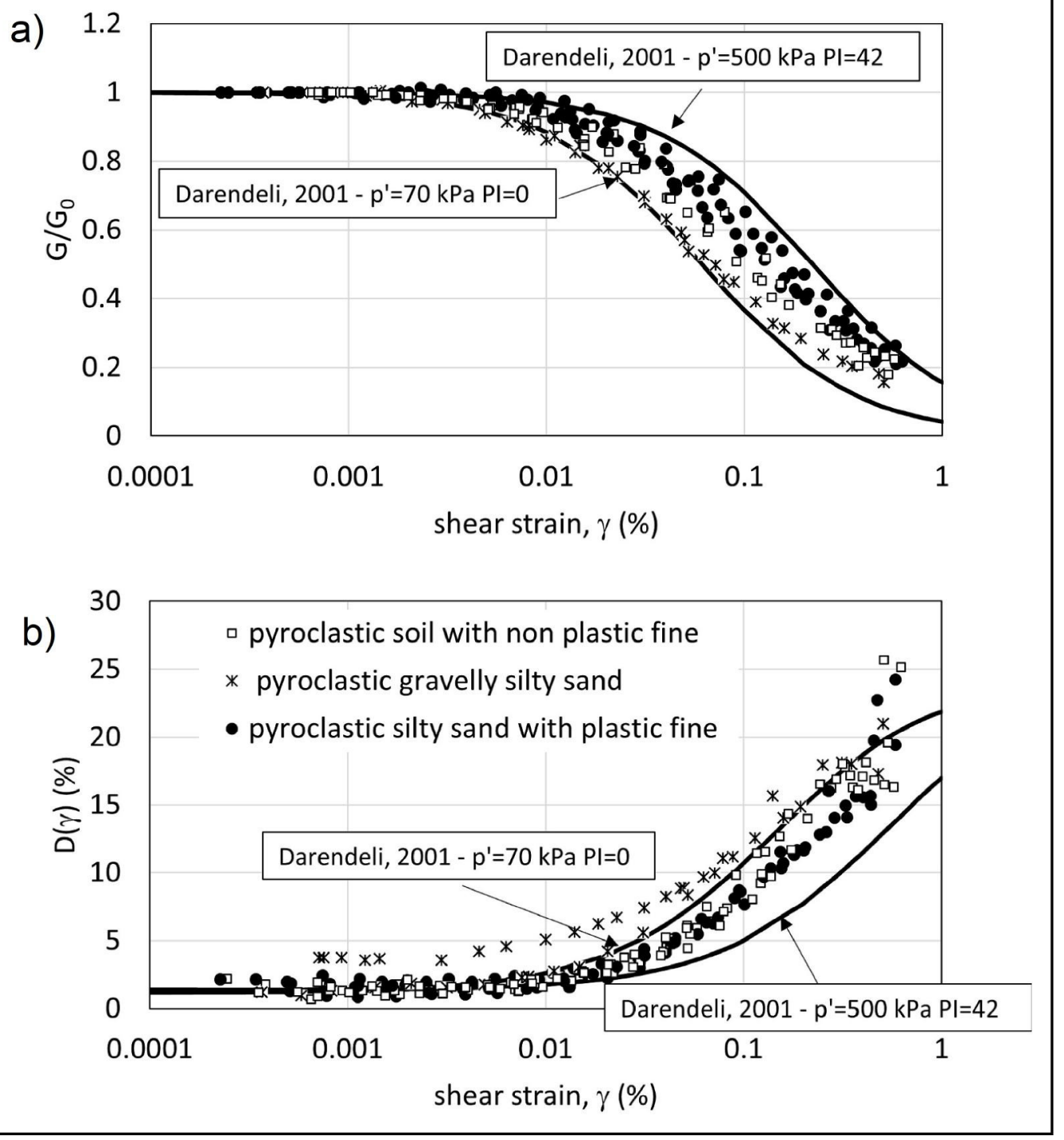

Fig. 11 - Results of laboratory tests in terms of (a) normalized stiffness $\mathrm{G}(\gamma) / \mathrm{G}_{0}$ and (b) damping ratio $\mathrm{D}(\gamma)$ with cyclic shear strain $\gamma$, compared with the DARENDELI (2001) curves. reason, the experimental data sets were used to calibrate the parameters of the general equations proposed by DARENDELI (2001), defining specific relationships to describe the non-linear behaviour of most of the silty, sandy and gravelly cover formations listed in table 1. An exception was made for the anthropogenic deposits, the fall-out silty sand and the fractured bedrock layers, for which literature curves relevant to similar materials were adopted (Alleanza et alii, 2021).

Figure 11 a-b shows the lower and upper bound curves relevant to the extreme cases in terms of confining mean stress, p', and plasticity index, PI, with the lowpressure and non-plastic conditions corresponding to the highest stiffness decay and increase of damping.

\section{MAP OF THE SEISMICALLY HOMOGENEOUS MICROZONES AND REPRESENTATIVE LOGS}

The collection of existing data permitted to reconstruct the conceptual model of the subsoil, with its geometric and parametric features. The new geophysical borehole and surface investigations allowed to increase the accuracy of the model in terms of $\mathrm{V}_{\mathrm{s}}$, and to define the position of the seismic bedrock, essential information for the numerical modelling.

The spatial variability of the near surface stratigraphy and of the related parameters is typically expressed by the map of the Seismically Homogeneous Microzones (SHM map; Gruppo di Lavoro MS, 2008; SM Working Group, 2015).

This map is shown in figure 12, where the whole study area is subdivided into stable zones prone to local amplification and zones prone to instability. Microzones are related to structural-stratigraphically and morphologically well-defined blocks: i.e. graben and horst structures bounded by high-angle normal faults, such as the Piazza Maio graben and the Grande Sentinella horst (Casamicciola), and the Panza blocks (Forio); pyroclastic and lava craters and complexes (Rotaro-Tabor Mts; Campotese-Panza mahars); lava domes and plateau (Zaro); cliffs, slopes and piedmont relieves of Mount Epomeo. 


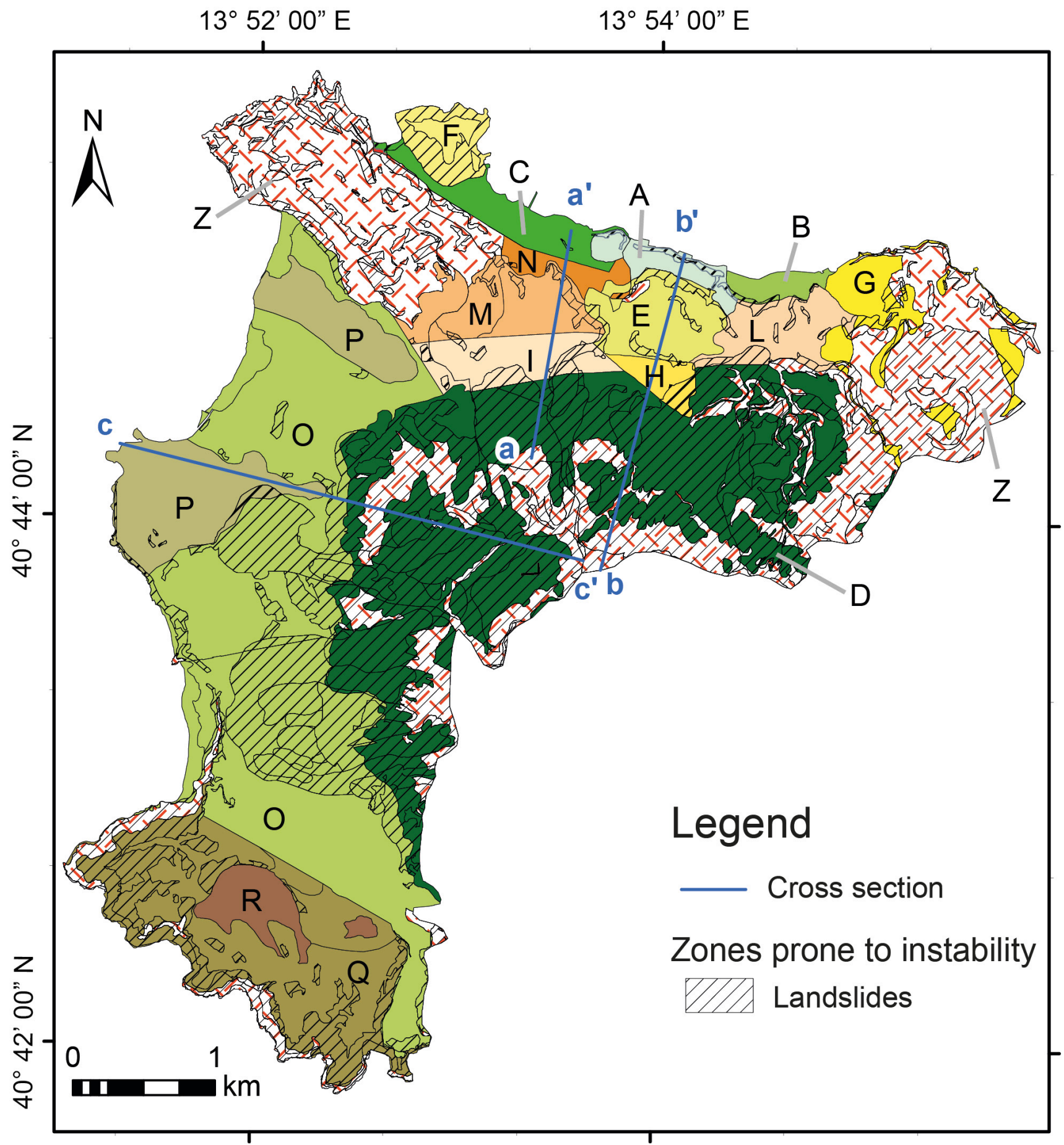

Fig. 12 - Map of the seismically homogeneous microzones. Capital letters refer to the microzones: A to R are stable zones prone to local amplification, while the $\mathrm{Z}$ microzone is the fractured bedrock. See also figure 13 for the type section of each microzone.

The extreme variability of subsoil conditions is thus well evidenced by the high number of detected microzones, each one of them identified by reference localities and represented by a typical subsoil column or type section (Fig. 13), which is the expression of the variable combination of high number of lithotypes according to the complex volcano-tectonic structure. The microzones are bounded in many cases by high angle faults, and are referred to graben- or horst-like structures; in other cases, they correlate to well distinguished morphological-stratigraphycal settings such as coastal terraces, plateau, or volcanic structures. The range of $\mathrm{V}_{\mathrm{s}}$ values indicated for each typical soil column derives from the averaging of measurements collected within or nearby each microzone. A red line evidence in each column (Fig. 13) the top of the seismic bedrock, showing $\mathrm{V}_{\mathrm{s}} \geq 800 \mathrm{~m} / \mathrm{s}$.

Zones prone to instability refer essentially to active landslides according to the IFFI (inventory of landslides of Italy) database for the Campania Region. 
1D AND 2D NUMERICAL MODELLING

\section{REFERENCE INPUT MOTION}

Seismic input to be propagated trough soil columns and cross-sections in $1 \mathrm{D}$ and $2 \mathrm{D}$ numerical modelling is represented by seven acceleration time-histories extracted from the Engineering Strong Motion database (ESM, http://esm.mi.ingv.it LuZI et alii, 2016). Selection was carried out by using a probabilistic approach (McGuIRE, 2001) aimed at selecting 5\%-damped elastic response spectra of signals records compatible with the elastic target response spectrum built according to NTC (2018) for a reference seismic action (expressed in terms of peak ground acceleration, PGA). In this case the reference PGA, corresponding to the reference probability of exceedance of $10 \%$ in 50 years and to a return period of 475 years, was assumed equal to $0.158 \mathrm{~g}$, which is the maximum reference PGA expected in the investigated area according to the PSHA map (OPCM, 2006; MeletTI et alii, 2006, 2008; STUCCH et alii, 2011; available at: http://esse1.mi.ingv.it).

Disaggregation analysis was performed by using the REXEL code (IERvolino et alii, 2009) to individuate the magnitude $\mathrm{M}$ and epicentral distance $\mathrm{R}$ intervals, in which the records to be searched should fall. For the investigated area the hazard is mainly due to events with Magnitude ranging from Mw 4.0 end 5.5 and distances between 0 and $20 \mathrm{~km}$.

The suite of accelerograms has been selected using the software InSpector (Acunzo et alii, 2014). Table 2 lists the seven-time histories used for the third level of seismic microzonation of the municipality of Casamicciola Terme, Lacco Ameno and Forio, while figure 14 graphically illustrates the corresponding spectra as well as their average value and the reference NTC18 spectra.

The source mechanism of the 2017 earthquake is related to normal faulting according to different authors (Sbrana et alii, 2018; De Novellis et alii, 2018), even if not unanimously accepted (BRAUN et alii, 2018; CALDERONI et alii, 2019); this observation guided the accelerogram selection. Nevertheless, three of the selected waveforms (namely EMCN.HNE, EMCN.HNN, and SVN) are characterized by focal mechanisms different from normal faulting; they were selected because recorded in a volcanic area and characterized by short epicentral distances and shallow hypocentral depth.

In this way, the compatibility of the characteristics of selected records was guaranteed not only with reference to the style of faulting that characterizes the study area, but also with respect to the specific seismo-tectonic context. This further control lays among the best practice in the input motion evaluation at the bedrock level (PAGLiaroli et alii, 2014), also considering that the faulting style plays a minor influence on the attenuation relationships of the main seismic motion parameters, as shown by Bommer et alii (2003).

Time histories were scaled according to the values of the scale factors SF reported in table 3 to match the reference spectrum in the $0.1-1.1 \mathrm{~s}$ periods interval. SF is defined as the ratio between the scaled and original PGA.

TABLE 2

List of the seven time histories of acceleration used for the third level of seismic microzonation of the Casamicciola Terme, Lacco Ameno and Forio municipalities.

\begin{tabular}{|c|c|c|c|c|c|c|}
\hline Record ID & $\begin{array}{l}\text { Event setting } \\
\text { and date } \\
\text { (dd/mm/yy } \\
\text { hh:mm:ss) }\end{array}$ & Station name & $\begin{array}{c}\text { Record } \\
\text { Component }\end{array}$ & Mw & $\begin{array}{c}\text { Epicentral } \\
\text { Distance }[\mathbf{K m}]\end{array}$ & $\begin{array}{l}\text { Hyp. depth } \\
\text { [Km] }\end{array}$ \\
\hline RM03 & $\begin{array}{c}\text { CENTRAL ITALY } \\
{[07 / 04 / 2009} \\
17: 47: 37]\end{array}$ & RM03 & $\mathrm{E} / \mathrm{O}$ & 5.5 & 3.4 & 17.1 \\
\hline $\mathrm{T} 1212$ & $\begin{array}{c}\text { CENTRAL ITALY } \\
{[26 / 10 / 2016} \\
17: 10: 36]\end{array}$ & T1212 & $\mathrm{N} / \mathrm{S}$ & 5.4 & 15.2 & 8.1 \\
\hline MRM & $\begin{array}{c}\text { SOUTHERN } \\
\text { ITALY } \\
{[25 / 10 / 2012} \\
23: 05: 24]\end{array}$ & MRM & $\mathrm{E} / \mathrm{O}$ & 5.2 & 2.4 & 9.7 \\
\hline OEQT & $\begin{array}{c}\text { NORTHERN } \\
\text { ITALY } \\
\text { [30/06/2013 } \\
14: 40: 08] \\
\end{array}$ & OEQT & $\mathrm{N} / \mathrm{S}$ & 4.5 & 3 & 6.1 \\
\hline EMCN.HNE & $\begin{array}{c}\text { SICILY, ITALY } \\
\text { [08/01/2019 } \\
23: 50: 34]\end{array}$ & EMCN & $\mathrm{E} / \mathrm{O}$ & $4.1\left(\mathrm{M}_{\mathrm{L}}\right)$ & 1.2 & 2.2 \\
\hline EMCN.HNN & $\begin{array}{c}\text { SICILY, ITALY } \\
\text { [08/01/2019 } \\
23: 50: 34] \\
\end{array}$ & EMCN & $\mathrm{N} / \mathrm{S}$ & $4.1\left(\mathrm{M}_{\mathrm{L}}\right)$ & 1.2 & 2.2 \\
\hline SVN & $\begin{array}{c}\text { SICILY, ITALY } \\
\text { [26/12/2018 } \\
02: 19: 17]\end{array}$ & SVN & $\mathrm{E} / \mathrm{O}$ & 4.9 & 4.5 & $<1.0$ \\
\hline
\end{tabular}


Stable zones prone to local amplification

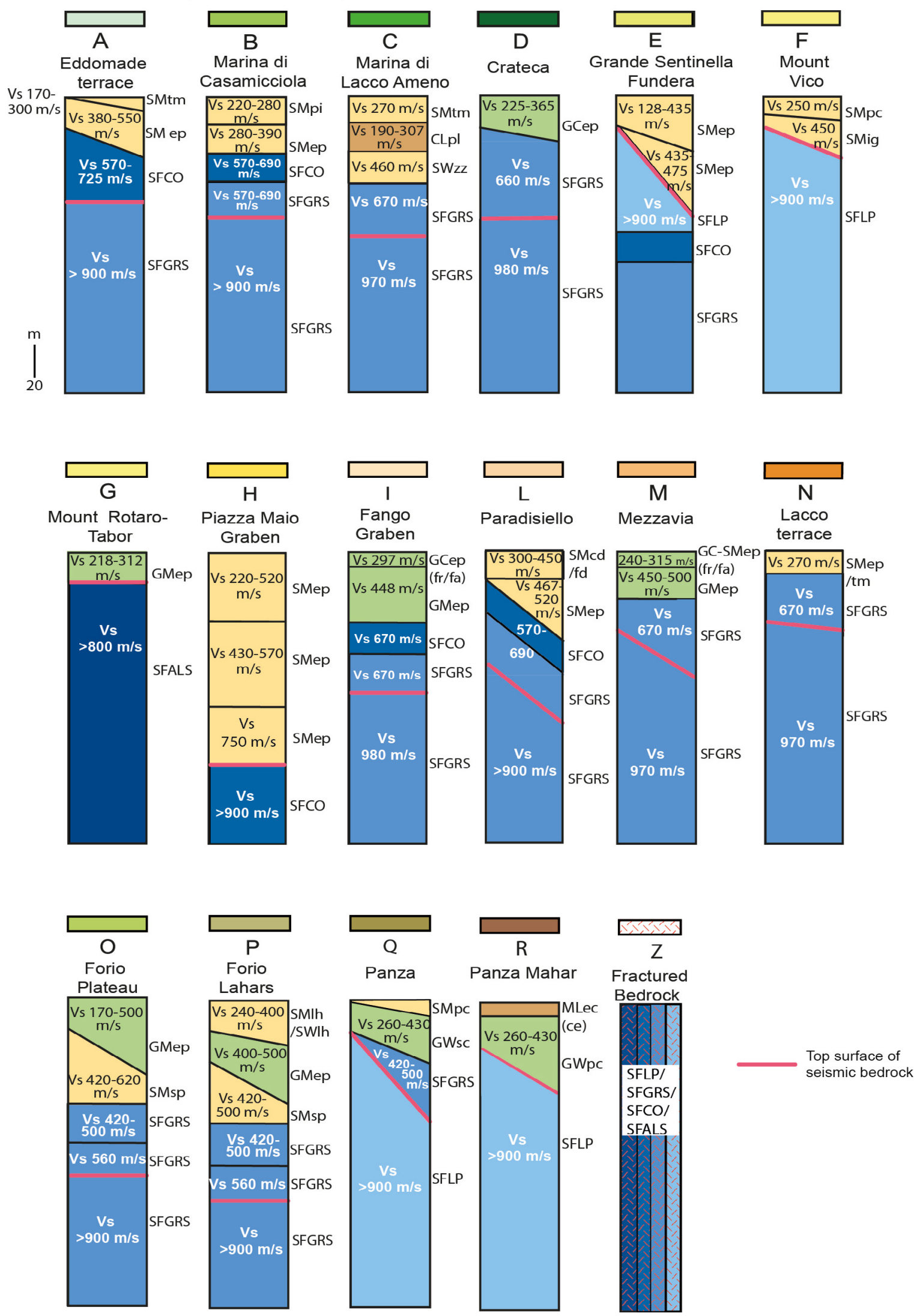

Fig. 13 - Stratigraphic columns representing type sections and type localities of each microzone shown on figure 12: A to $\mathrm{R}$ are the stable zones prone to local amplification. Columns are composed of the lithotypes represented in figures 4 and 7 (see table 1 for the related codes); Vs values, associated with the lithotypes, derive from the available geophysical data: DH and MASW tests, 2D seismic arrays. In each column the red line indicates the top surface of seismic bedrock, with shear wave velocity $\mathrm{V}_{\mathrm{s}} \geq 800 \mathrm{~m} / \mathrm{s}$. The $\mathrm{Z}$ microzone represents the fractured bedrock. 


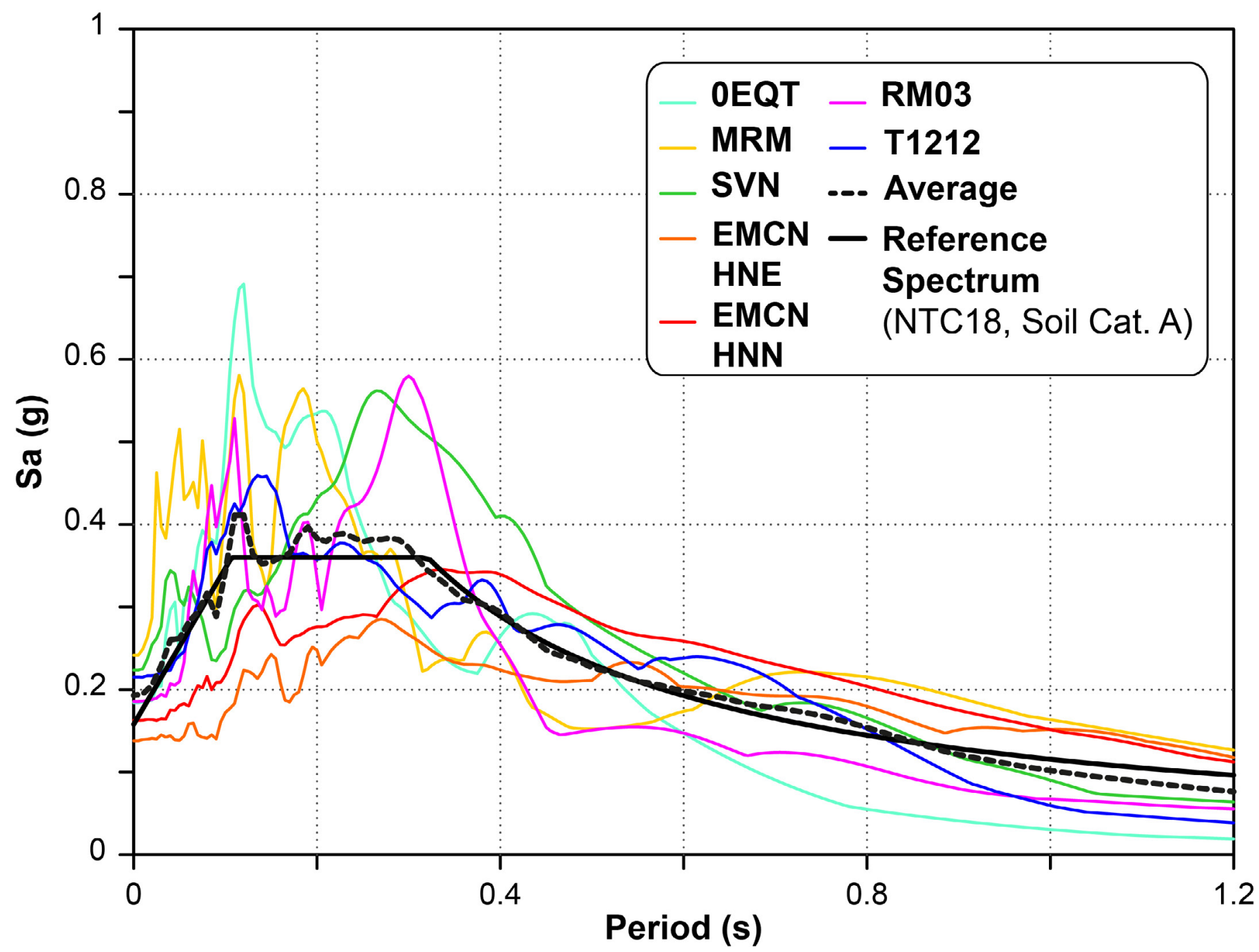

Fig. 14 - Input in numerical modelling featured by 5\%-damped elastic response spectra of signals records (coloured curves). Black and grey thick lines indicate respectively the reference and average spectra (NTC18).

The range of periods for the spectrum compatibility is chosen according to the current best practice in records selection for the Grade 3 microzonation studies (LuzI et alii, 2020). For sake of completeness, table 3 reports the scale factor, SF, and the average root-mean-square deviation of the observed spectrum from the target design spectrum, DRMS (Bommer \& AcEvedo, 2004), useful to describe the quality of the match. The values of Arias intensity, Ai, and the significant duration, SD are also reported in the same table to give account on the energy content of the selected accelerograms.

\section{SEISMIC RESPONSE ANALYSES}

The seismic site response of the study area was evaluated carrying out one-dimensional (1D) analyses along layered soil profiles characterizing each microzone (i.e., the typical soil columns in figure 13) and twodimensional (2D) analyses along selected cross-sections running from the Mount Epomeo to the coast (Figs. 4 and 7). The physical, mechanical, and non-linear properties
TABLE 3

Main parameters describing the suite of accelerograms:

$\mathrm{SF}$ is the applied scale factor; $\mathrm{D}_{\mathrm{RMS}}$ is the average rootmean-square deviation of the observed spectrum from the target design spectrum; $\mathrm{Ai}$ is the Arias intensity; SD is the significant duration.

\begin{tabular}{|c|c|c|c|c|c|}
\hline $\begin{array}{c}\text { Record } \\
\text { Name }\end{array}$ & $\begin{array}{c}\text { Soil } \\
\text { Category } \\
(\mathrm{NTC}, 2018)\end{array}$ & $\mathrm{SF}$ & $\mathrm{D}_{\mathrm{RMS}}$ & $\begin{array}{c}\mathrm{Ai} \\
{[\mathrm{cm} / \mathrm{s}]}\end{array}$ & $\mathrm{SD}[\mathrm{s}]$ \\
\hline RM03 & $\mathrm{A}^{*}$ & 2.0 & 0.045 & 14.48 & 3.625 \\
\hline T1212 & $\mathrm{A}^{*}$ & 1.1 & 0.041 & 10.75 & 3.755 \\
\hline MRM & $\mathrm{A}$ & 1.3 & 0.056 & 18.06 & 2.99 \\
\hline EMCN.HNE & $\mathrm{N} / \mathrm{A}$ & 1.28 & 0.039 & 7.53 & 3.49 \\
\hline $\begin{array}{c}\text { EMCN. } \\
\text { HNN }\end{array}$ & N/A & 1.28 & 0.036 & 8.26 & 2.405 \\
\hline 0EQT & $\mathrm{A}^{*}$ & 1.6 & 0.056 & 14.28 & 1.65 \\
\hline SVN & $\mathrm{A}^{*}$ & 0.4 & 0.033 & 13.89 & 1.945 \\
\hline
\end{tabular}


adopted in the numerical analyses are reported in detail by AllEanza et alii (2021) and are summarized in the tables S2 reported in the Supplementary materials. The depth and morphology of seismic bedrock were defined based on geological and geophysical surveys and checked comparing the numerical amplification functions with the experimental HVSR spectral ratios resulting from environmental noise measurements. A linear visco-elastic behavior with a constant damping ratio equal to $0.5 \%$ was assigned to the seismic bedrock.

1D analyses were carried out adopting the code STRATA (KоTTKE \& RATHJE, 2008) operating in the frequency domain, while the QUAD4M finite element code (Hudson et alii, 2003) was used for 2D simulations in the time domain; in both cases, the equivalent linear approach was used to account for non-linear and hysteretic soil behaviour. The analysis domain of the selected 2D sections was obtained by artificially extending the lateral borders to simulate one-dimensional conditions and avoid unrealistic reflections. The lower boundary of the domain, where the input motions were applied, was also placed at a depth large enough not to generate interference between direct and indirect waves. For both types of analysis, the characteristic dimension of the elements was limited through the KUHLEMEYER \& LYSMER (1973) relationship, considering a maximum frequency of $20 \mathrm{~Hz}$.

The results of both 2D and 1D analyses were synthesized adopting the amplification factor defined as:

$$
A F=\frac{\int_{T_{a}}^{T_{b}} S a_{,}(T) d T}{\int_{T_{a}}^{T_{b}} S a_{, r}(T) d T}
$$

where $S_{a, s}(T)$ and $S_{a, r}(T)$ are the spectral accelerations of ground motion at the surface and the bedrock, respectively. The amplification factor was calculated considering three range of periods $\left(T_{a}, T_{b}\right)$ : low $(0.1-0.5 s)$, medium $(0.4-0.8 s)$ and high (0.7-1.1s).

In figures 15, 16 and 17 (panels from a to c), the mean, maximum and minimum values of the amplification factors, $\mathrm{AF}$, computed for the seven input motions within the three ranges of periods are shown with colored continuous and dotted lines, respectively. The values of AF obtained from 1D analyses are also reported, with empty circles, for comparison. In the same plots, the black lines represent the value of $\mathrm{AF}$ assigned to each microzone for the final mapping.

Figure 15 shows the variation of AF along the b-b' crosssection (Casamicciola Terme). The 2D amplification effects appear significant throughout the Grande Sentinella relief (zone E) and southward of it, within the Maio graben (zone $\mathrm{H})$, where the 1D amplification factors are lower than the 2D ones whatever the periods range. This result can be attributed to $2 \mathrm{D}$ resonance, respectively due to shallow and deep morphological factors particularly at medium and high periods. In fact, both the topographic irregularity along the relief and the buried geometry of the graben are expected to focalize the seismic waves towards the center of the relevant microzones $\mathrm{E}$ and $\mathrm{H}$, inducing significant amplification of the seismic motion therein.

Two-dimensional amplification effects are not observed as much significant along the Fango graben (zone I) characterizing the cross-section a-a' shown in figure 16. Apparently, the section a-a' crossing downhill the municipality of Lacco Ameno is characterized by a morphology very similar to the b-b' section of Casamicciola Terme (Fig. 15). However, in this case, the graben structure located between the distances $1100 \mathrm{~m}$ and $1450 \mathrm{~m}$ does not appear to generate significant $2 \mathrm{D}$ resonance. The difference between the seismic response in the two grabens may be due to their different aspect ratio, relatively broad and shallow the Fango graben (zone I), narrow and deep the Maio graben (zone $\mathrm{H}$ ), narrow and deep the Maio graben, that in the case of Maio would increase focalization of seismic waves.

On the other hand, amplification appears more fluctuating along the coastline between distances $1900 \mathrm{~m}$ and $2200 \mathrm{~m}$ (microzones E, Ca and $\mathrm{Cb}$ of Fig. 16), due to both the irregular topographic profile and a significant impedance contrast between the bedrock and the soil covers. In particular, the presence of a shallow layer of deformable marine sand (SMtm litotype) seems to further enhance the local topography effect of the costal terrace. It can be noted that 2D amplification for low and medium periods is higher than that resulting from 1D analyses, but the opposite occurred for the highest periods, due to the reduced ratio between the morphological irregularity and the dominant wavelengths of the ground motion.

Due to the quite regular topography, almost negligible 2D amplification effects were highlighted along the section c-c' (Forio) drawn in figure 17, except for the zone on the flank of Mount Epomeo (microzone O): therein, the edge effects induce a local attenuation of the ground motion, hence a $2 \mathrm{D}$ amplification factor is lower than that computed by $1 \mathrm{D}$ analysis.

\section{MICROZONATION MAPS}

The results of all $1 \mathrm{D}$ and $2 \mathrm{D}$ analyses were finally synthetized into three maps showing the distribution of amplification factors, AF, computed within the three ranges of periods considered and associated to selected microzones (Fig. 18a, b and c). The amplification factors were indeed calculated and mapped only on selected parts of the three municipalities, namely the historical centers and the hamlets with a significant presence of old buildings.

The criteria adopted to produce the microzonation maps of figure 18 required that, for each microzone and range of periods: i) the value of the amplification factor obtained from the two-dimensional modelling was an averaged result between those obtained at each output point of the model; ii) when both one-dimensional and two-dimensional modelling were carried out in the same microzone the more conservative, and therefore higher, value of amplification factor was chosen, thus following a precautionary criterion.

The significant heterogeneity of the cover units and their variable thickness are reflected by the high spatial variability of amplification factors within each period range. On the average, amplification factors at high periods $(\mathrm{T}=0.7-1.1 \mathrm{~s})$ decrease from the grabens of Casamicciola Terme and Fango towards the coast. By contrast, the highest AFs at lower periods $(\mathrm{T}=0.1-0.5 \mathrm{~s}$ interval $)$ are mostly localized along the coast: this behaviour is generally linked to the lithological heterogeneities, which consequently may cause seismic waves scattering.

The highest amplification factors are attained in the graben of Piazza Maio at Casamicciola characterized by 


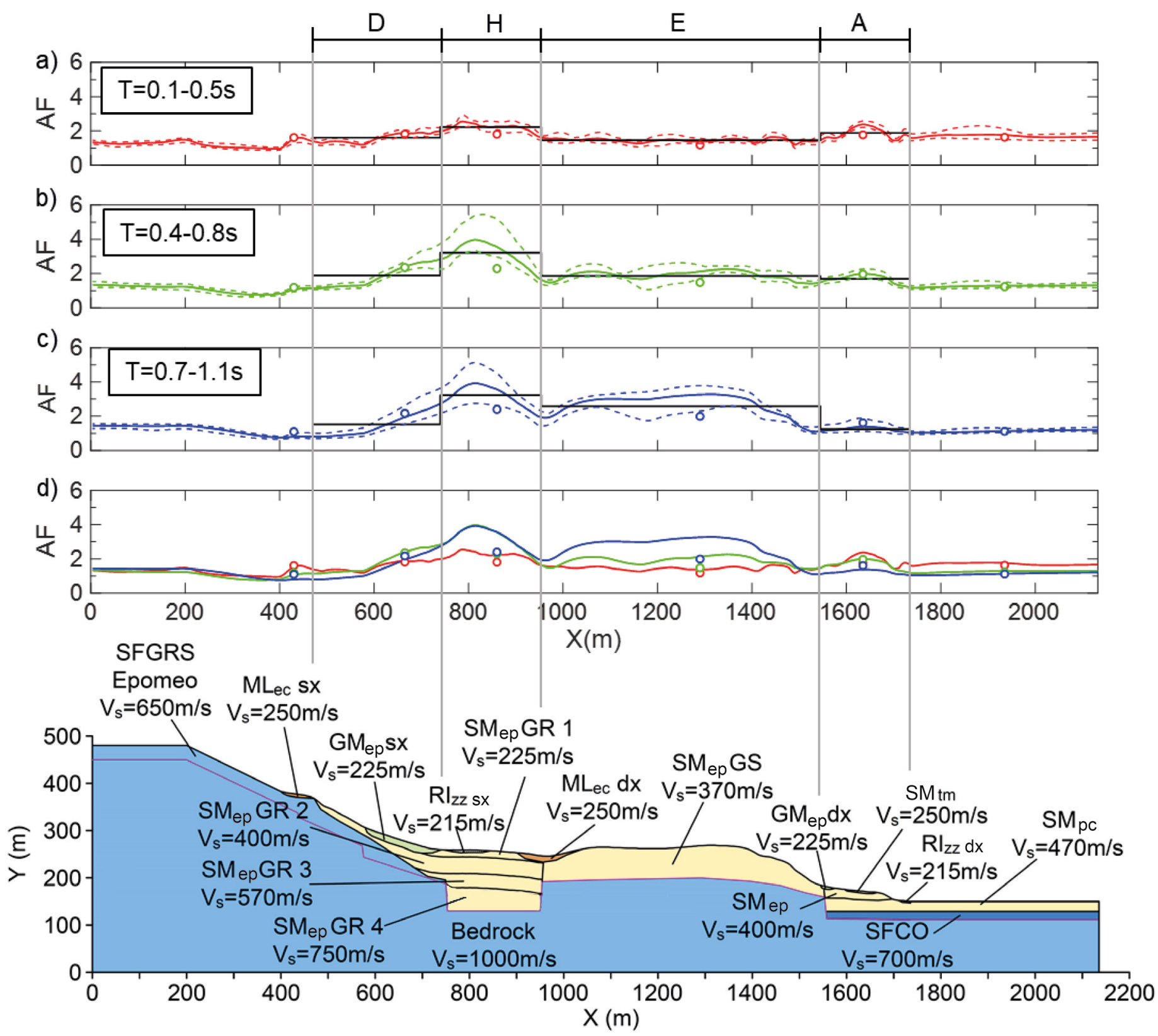

\section{Legend}

$T=0.1-0.5 \mathrm{~s}$

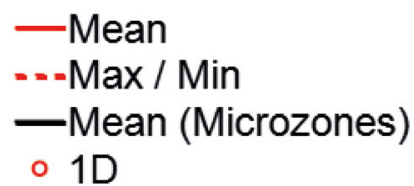

$T=0.4-0.8 \mathrm{~s}$

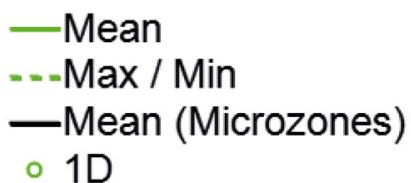

$\mathrm{T}=0.7-1.1 \mathrm{~s}$

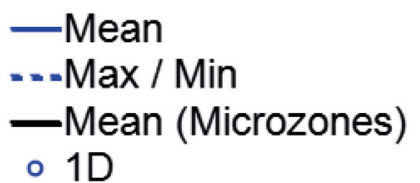

— Seismic Bedrock

Fig. 15 - Amplification Factors computed along the b-b' cross section (Casamicciola Terme) for: a) low; b) medium; c) high periods; d) comparison among the mean profiles. The bar line on top shows the crossed microzones.

amplifications greater than 3 in the ranges of medium and high periods. Hence, it is not surprising that in this area the highest damages occurred both in 1883 and in 2017 (see figure 1). At low periods, instead, the highest amplifications are predicted along the coastal area of Lacco Ameno, due to the above described topographic and stratigraphic irregularities. It can be also observed that Panza, the hamlet in the south-westernmost part of the island, shows significantly higher $\mathrm{AF}$ values if compared to those predicted at Forio centre, for all the period ranges. This latter anomaly seems to be well correlated to the elongation of the isoseismal map 


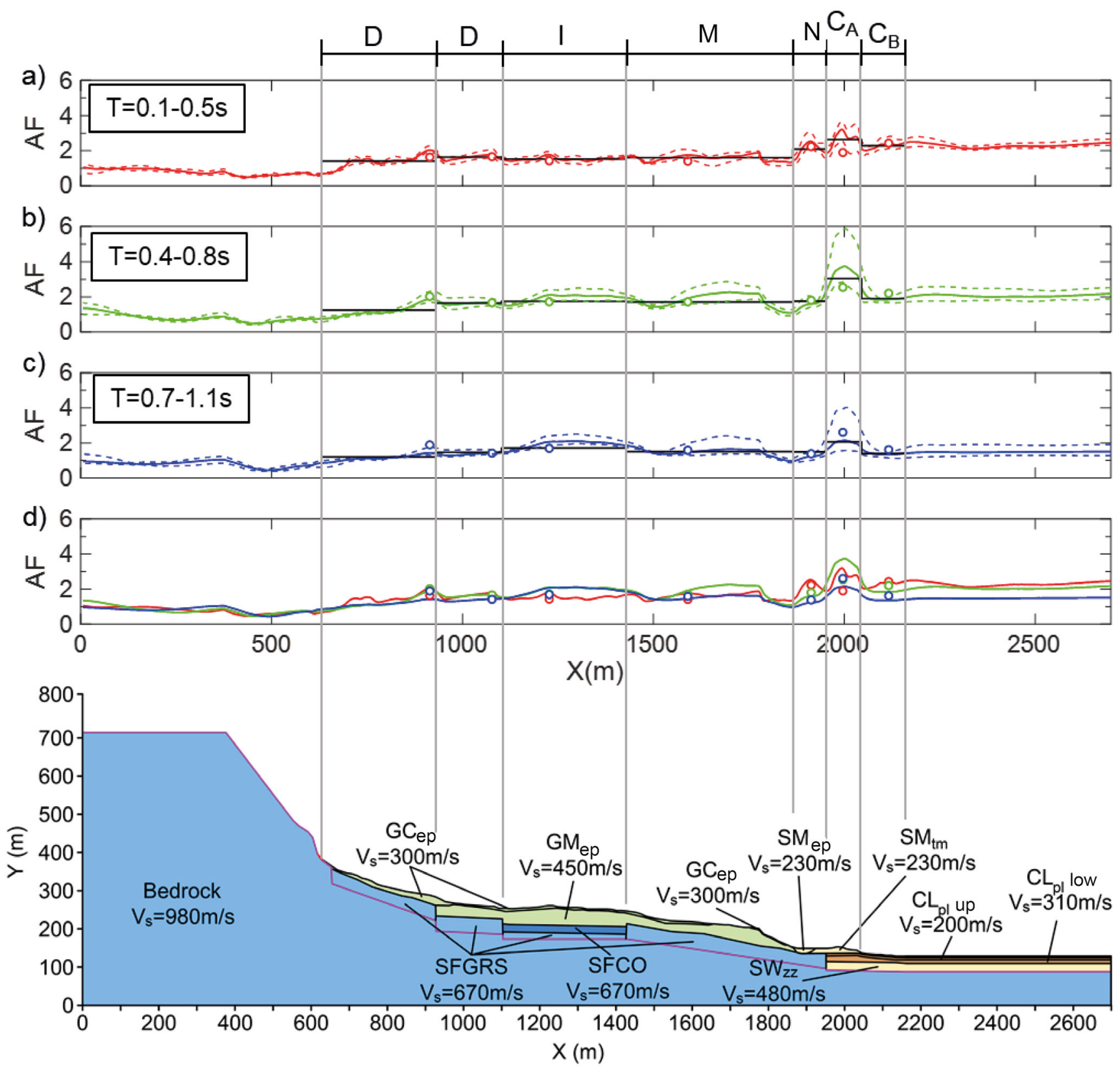

Legend

$\mathrm{T}=0.1-0.5 \mathrm{~s}$

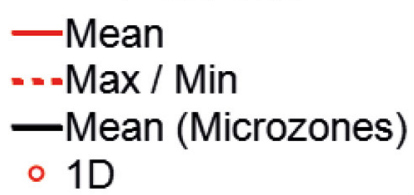

$\mathrm{T}=0.4-0.8 \mathrm{~s}$

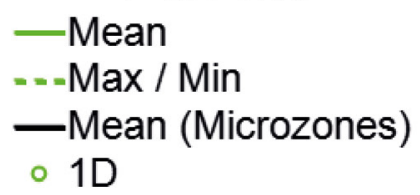

$\mathrm{T}=0.7-1.1 \mathrm{~s}$

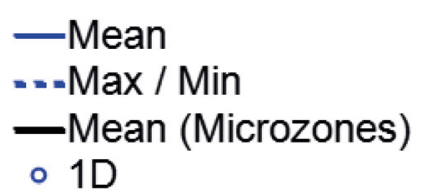

— Seismic Bedrock

Seismic Bedrock

Fig. 16 - Amplification Factors computed along the a-a' cross section (Lacco Ameno) for: a) low; b) medium; c) high periods; d) comparison among the mean profiles. The bar line on top shows the crossed microzones.

towards the southern part of the island during the 1883 event (Fig.1c).

The quantitative and detailed assessment of the influence of local subsoil conditions on ground-motion has a great interest for seismic risk mitigation purposes, especially during the post-event reconstruction still ongoing. Most of the buildings in the zoned areas are old masonry structures, one to three-storey high, implying that the AF distribution relevant to this building class is that referring to the low period range (see also Pergalani et alii, 2020, for the correlation between period range and number of stories). 


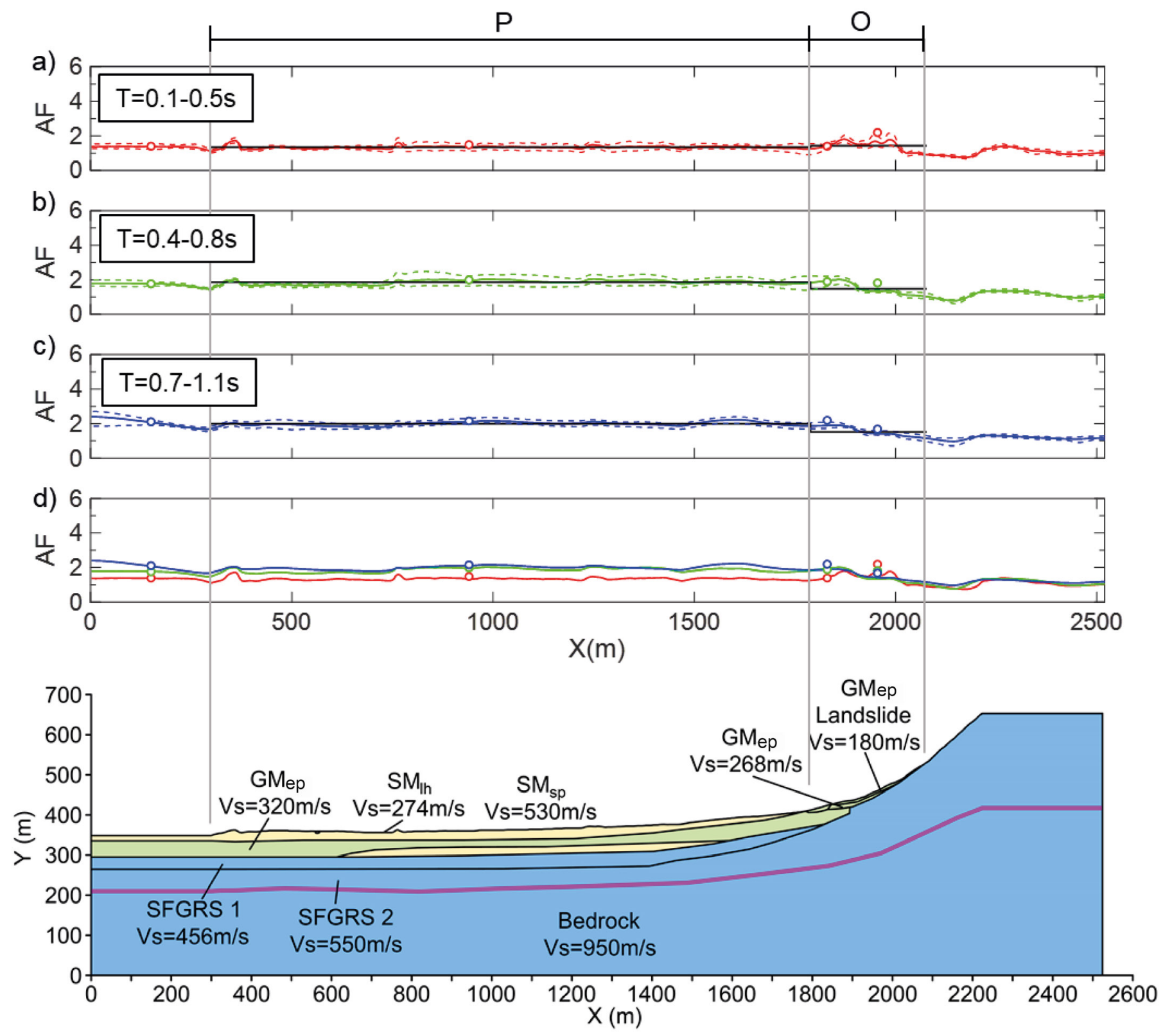

Legend
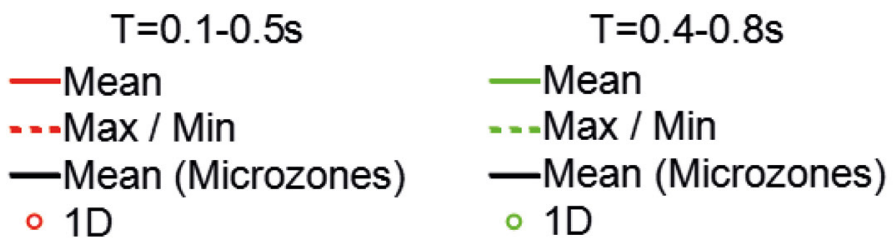

$\mathrm{T}=0.7-1.1 \mathrm{~s}$

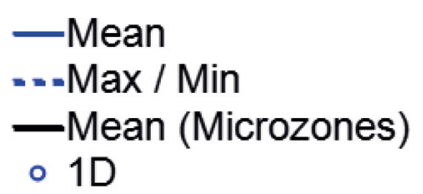

—Seismic Bedrock

Fig. 17 - Amplification Factors computed along the c-c' cross section (Forio) for: a) low; b) medium; c) high periods; d) comparison among the mean profiles. The bar line on top shows the crossed microzones.

Figure 18d highlights, for the different period ranges, the AF values distribution. Noteworthy, a slightly increase of the AFs median values characterizes the study area, going from the $\mathrm{T}=0.1-0.5 \mathrm{~s}$ (1.8) to the $\mathrm{T}=0.4-0.8 \mathrm{~s}$ interval (1.9), while for the last period interval of $\mathrm{T}=0.7-1.1 \mathrm{~s}$, the median value is the lowest (1.5). This apparently seems in contrast with the suggestion of the seismologists and engineers Mercalli, Giordano and Camotto in MAROTTA et alii (2019), who recommended to realize one-story buildings, but observing the AF distribution in figure $18 \mathrm{~d}$ it can be 

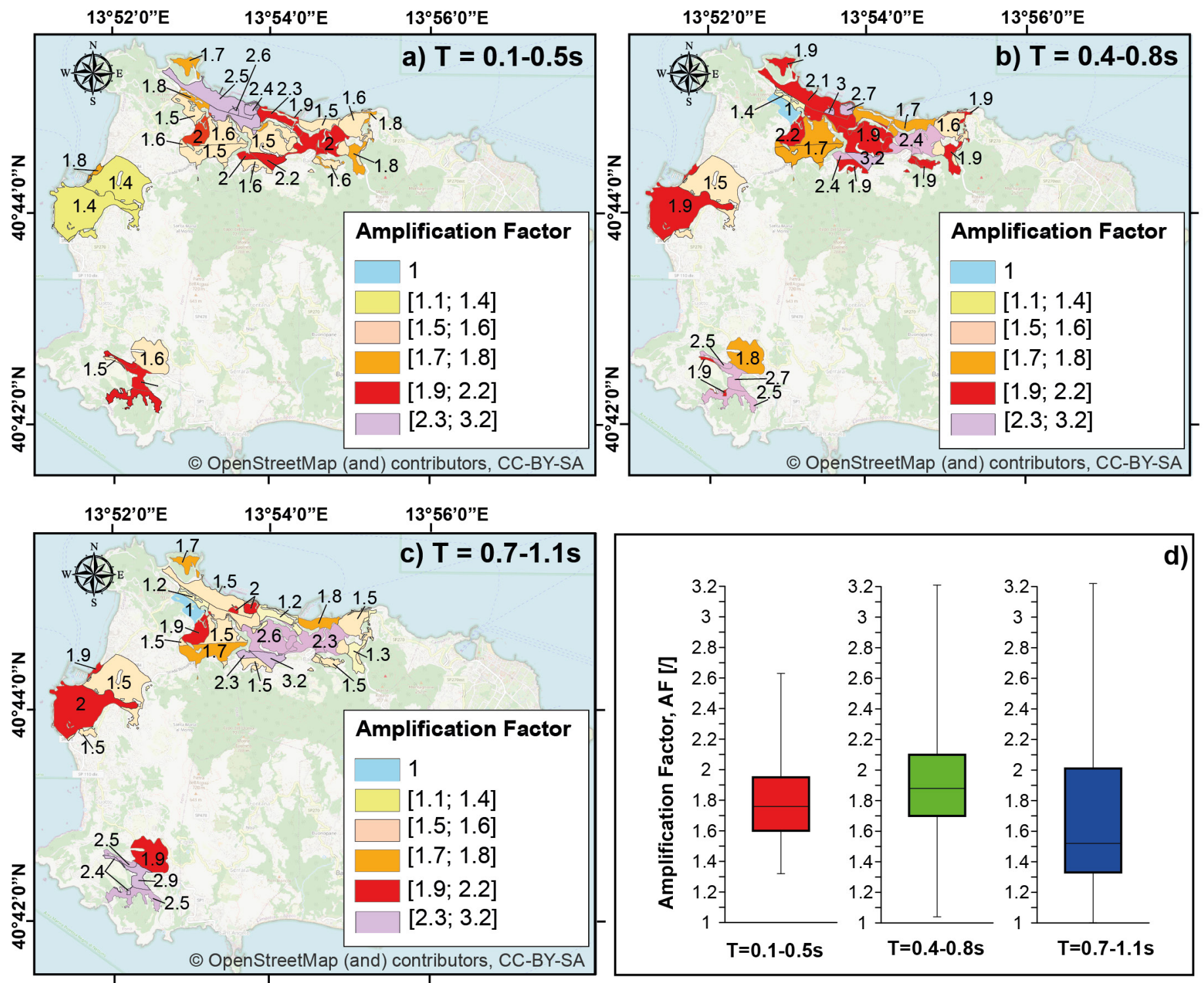

\section{Meters}

Fig. 18 - a) Seismic Microzonation (SM) map in the T=0.1-0.5 s interval of period; b) SM map in the T=0.4-0.8 s interval of period; c) SM map in the $\mathrm{T}=0.7-1.1 \mathrm{~s}$ interval of period; $\mathrm{d}$ ) Distribution of Amplification Factors (AF) derived from SM study as whisker plots: minimum, $25^{\text {th }}$ percentile, median, $75^{\text {th }}$ percentile and maximum.

noticed that the widest range of distribution is localized in the period interval $0.7-1.1 \mathrm{~s}$. In fact, the variability of AF increases with $\mathrm{T}$, highlighting the necessity of concentrating the attention on the vulnerability of the medium to highrise buildings where the corresponding AF exceeds the median value, and of individuating the areas with highest priority for more accurate subsoil investigations and further seismic response analyses.

Finally, for a further application of microzonation maps, the availability of amplification factors may allow to compute the overall seismic hazard of the studied area with the introduction of the parameter $\mathrm{H}_{\mathrm{SM}}$, which establishes an absolute ranking of seismic hazard (Mori et alii, 2020; FALCONE et alii, 2020). In this perspective, the 3 Grade SM studies discussed in this paper involve the advantage of a possible immediate use in terms of seismic classification of the territory in order to prioritize assessment and strengthening of existing structures.

\section{CONCLUSIONS}

The Grade 3 SM studies performed on the Ischia Island have allowed to identify microzones characterized by high values of amplification factor, up to 2.6-3.2, in the entire range of periods considered. These microzones correspond to densely urbanized areas where site effects are expected due to the local shallow stratigraphy and morpho-structural setting. In particular, results from the 1D and 2D numerical modelling suggest that: i) in the 
narrow and relatively deep graben-like basin of Maio, 2D resonance effects can be likely hypothesized; ii) the topographic irregularities of the terraced northern coastal belt, coupled with local stratigraphy, determine resonance effects at low and medium periods; iii) relatively low amplification effects, mostly of stratigraphic type, are obtained in correspondence of the relatively flat Forio lowland with a tabular, multi-layered stratigraphic architecture.

As a final remark, the authors wish to recommend to expand the above grade $3 \mathrm{SM}$ study, which was addressed to manage the emergency, even to other portions of the Ischia Island. The subsoil investigations deserve to be extended even to the wide areas susceptible of instability, which were left out in this study although they are populated as much as the others. In future investigations for land use planning, the present study can be taken as a reference for describing the great variability of subsoil conditions and the main effects played by them on site amplification. Once having individuated the dominant factors controlling site amplification, urban planning policies able to correctly consider them should be actuated, in order to correctly address interventions to reduce the vulnerability of the building stock. Thus, considering the potential use of grade 3 seismic microzonation studies, the case study of Ischia represents a possible reference for other complex volcano-tectonic areas both in Italy, such as in the Vesuvius, Eolian Isles and Etna, and in other regions of the world.

\section{ELECTRONIC SUPPLEMENTARY MATERIAL}

This article contains electronic supplementary material which is available to authorised users.

\section{ACKNOWLEDGMenTs}

The authors wish to thank the Commissario straordinario di Governo per gli interventi nei territori dei Comuni di Casamicciola Terme, Forio, Lacco Ameno and his staff, the Dipartimento della Protezione Civile, the Regione Campania-Direzione Generale Governo del Territorio (Staff 500994), and the Municipalities of Casamicciola Terme, Forio and Lacco Ameno for actively supporting the organization of SM studies. Prof. S. Catalano, an anonymous reviewer and the editors are acknowledged for the useful comments and suggestions that greatly improved the manuscript.

This research was financially supported in the frame of the CNR DTA.AD003.378 Project "Ischia 2018: Supporto e coordinamento scientifico per la realizzazione degli studi di microzonazione sismica di III livello nei territori dei Comuni dell'isola di Ischia".

\section{REFERENCES}

Abate G., Bramante S. \& Massimino M.R. (2020) - Innovative Seismic Microzonation Maps of Urban Areas for the Management of Building Heritage: A Catania Case Study. Geosciences 10, 480. https://doi.org/10.3390/geosciences10120480.

Acocella V. \& Funiciello R. (1999) - The interaction between regional and local tectonics during resurgent doming: the case of the island of Ischia, Italy. Journal of Volcanology and Geothermal Research, 88, 109-12.

Acunzo G., Pagliaroli A. \& Scasserra G. (2014) - In-Spector: un software di supporto alla selezione di accelerogrammi naturali spettrocompatibili per analisi geotecniche e strutturali. $33^{\circ}$ Convegno Nazionale GNGTS, Bologna 25-27 Novembre 2014, volume 2, 107-114, ISBN: 978-88-940442-2-5.
Albarello D. (2017) - Extensive application of seismic microzoning: methodological and sociopolitical issues in the Italian experience. Bollettino di Geofisica Teorica ed Applicata, 58(4), 253-264.

Alleanza G.A., d'Onofrio A. Gargiulo F., Silvestri F., Mancini M. Gaudiosi I., Caciolli M.C., Cavuoto G., Di Fiore V., Milana G. \& Vassallo M. (2021) - Valutazione della risposta sismica locale di alcune aree dell'Isola di Ischia per la pianificazione di interventi di mitigazione del Rischio Sismico. Memorie del XXVII Convegno Nazionale di Geotecnica "La geotecnica per lo sviluppo sostenibile del territorio e per la tutela dell'ambiente", Reggio Calabria 9-11/02/2022 (in press).

Azzaro R., Carocci C.F., Maugeri M. \& Torrisi A. (2010) - Microzonazione sismica del versante orientale dell'etna. studi di primo livello. Regione siciliana-Dipartimento della Protezione civile. Le nove muse Editrice. ISBN 978-88-87820-45-4.

Azzaro R., Del Mese S., Graziani L., Maramai A., Martini G., Paolini S., Screpanti A., Verrubbi V., Arcoraci A., \& Tertulliani A. (2017) QUEST - Rilievo macrosismico per il terremoto dell'isola di Ischia del 21 agosto 2017. Rapporto finale. Rapporto Interno INGV. Napoli: INGV. https://doi.org/10.5281/zenodo.886047.

Benjamin J., Rovere A., Fontana A., Furlani S., Vacchi M., Inglis R.H., Galili E., Antonioli F., Sivan D., Miko S., Mourtzas N., Felua I., Meredith-Williams M., Goodman-Tchernov B., Kolaiti E., Anzidei M. \& GeHrels R. (2017) - Late Quaternary sea-level changes and early human societies in the central and eastern Mediterranean Basin: An interdisciplinary review. Quaternary International, 449, 29-57.

Bommer J. J., Douglas J. \& Strasser F.O. (2003) - Style-of-faulting in ground-motion prediction equations. Bulletin of Earthquake Engineering, 1(2), 171-203.

Bommer J.J. \& Acevedo A.B. (2004) - The use of real earthquake accelerograms as input to dynamic analysis. Journal of Earthquake Engineering, 8, Spec. Issue, 1, 43-91.

Braun T., FAMiani D. \& CESca S. (2018) - Seismological constraints on the source mechanism of the damaging seismic event of 21 August 2017 on Ischia Island (Southern Italy). Seismological Research Letters, 89, 1741-1749.

Calderoni G., Di Giovambattista R., Pezzo G., Albano M., Atzori S. Tolomei C., Ventura G. (2019) - Seismic and Geodetic Evidences of a Hydrothermal Source in the Md 4.0, 2017, Ischia earthquake (Italy). Journal of Geophysical Research, 124, 5014-5029.

CANCANI A. (1904) - Sur l'emploi d'une double échelle sismique des intensité, empirique et absolue. Proceedings of the C.R. des Séances de la deuxième Conference Seismologique Internationale réunie a Strasbourg, Leipzig 1903. Gerlands Beitrage zur Geophysik II (Strasbourg), 281-283.

Carlino S., Cubellis E. \& Marturano A. (2010) - The catastrophic 1883 earthquake at the island of Ischia (southern Italy): macroseismic data and the role of geological conditions. Natural Hazards 52, 231. https://doi.org/10.1007/s11069-009-9367-2.

Cavinato G.P., Mancini M., Scarascia Mugnozza G. \& Working Group (2018) - "Primi interventi urgenti di protezione civile conseguenti all'evento sismico che ha interessato il territorio dei comuni di Casamicciola Terme, di Forio e di Lacco Ameno dell'Isola di Ischia il giorno 21 agosto 2017. Relazione Finale", OCDPC n. 476 del 29 agosto 2017. CNR IGAG, Roma.

COMMISSIONE TECNICA PER LA MICROZONAZIONE SISMICA (2020). Microzonazione sismica. Standard di rappresentazione $e$ archiviazione informatica. Versione 4.2. Presidenza del Consiglio dei Ministri-Dipartimento della Protezione Civile, Conferenza delle Regioni e delle Provincie Autonome, Roma, pp. 138.

Cubellis E. \& Luongo G. (1998a) - Il terremoto del 28 luglio 1883. Danni, vittime ed effetti al suolo. In: Luongo G. (ed.) Il terremoto del 28 luglio 1883 a Casamicciola nell'isola d'Ischia, Presidenza del Consiglio dei Ministri, Dipartimento per i Servizi Tecnici Nazionali, Servizio Sismico Nazionale, 59-100.

Cubellis E. \& Luongo G. (1998b) - Il terremoto del 28 luglio 1883 Campo macrosismico e studio della sorgente. In: Luongo G. (ed.) Il terremoto del 28 luglio 1883 a Casamicciola nell'isola d'Ischia, Presidenza del Consiglio dei Ministri, Dipartimento per i Servizi Tecnici Nazionali, Servizio Sismico Nazionale, 101-110.

DARENDELI M.B. (2001). Development of a new family of normalised modulus reduction and damping curves. Ph.D. thesis Dept. of Civil Eng., The University of Texas, Austin, U.S.A.

Della Seta M., Esposito C., Marmoni G.M., Martino S., Paciello A., Perinelli C. \& Sottili G. (2015) - Geological constraints for a 
conceptual evolutionary model of the slope deformations affecting Mt. Nuovo at Ischia (Italy). Italian Journal of Engineering Geology and Environment, 2, 15-28.

Del Prete S. \& Mele R. (1999) - L'influenza dei fenomeni di instabilità di versante nel quadro morfoevolutivo della costa dell'isola d'Ischia. Bollettino della Società Geologica Italiana, 118, 339-360

Del Prete S. \& Mele R. (2006) - Il contributo delle informazioni storiche per la valutazione della propensione al dissesto nell'Isola d'Ischia (Campania). Rendiconti della Società Geologica Italiana, Nuova Serie, 2, 29-47

De Novellis V., Carlino S., Castaldo R., Tramelli A., De luca C., Pino N. A., Pepe S., Convertito V., Zinno I., De Martino P., Bonano M. Giudicepietro F., Casu F., Macedonio G., Manunta M., Cardaci C. Manzo M., Di Bucci D., Solaro G., Zeni, Lanari R., Bianco F. \& TizzANI, P. (2018) - The 21 August 2017 Ischia (Italy) earthquake source model inferred from seismological, GPS, and DInSAR measurements. Geophysical Research Letters, 45(5), 2193-2202.

De Rossi M.S. (1884) - Raccolta di fatti, relazioni, bibliografie sul terremoto di Casamicciola del 28 Luglio 1883 con breviosservazioni. Bullettino del Vulcanismo Italiano, 11, 65-131, Roma, http:// storing.ingv.it/cfti/disclaimer.html.

D'Onofrio A., Silvestri F. \& Vinale F. (1999). A new torsional shear device. ASTM Geotechnical Testing Journal, 22(2), 107-117. https://doi.org/10.1520/GTJ11269J.

EMERGEO WORKING GROUP (2019) - A photographic collection of the coseismic geological effects induced by the 21 August 2017, M=4, Casamicciola earthquake (Ischia island, Italy). Miscellanea INGV, 50, pp 90. ISSN 2039-6651

Falcone G., Mendicelli A., Mori F., Fabozzi S., Moscatelli M., Occhipinti G. \& Peronace E (2020). A simplified analysis of the total seismic hazard in Italy. Engineering Geology, 267, 105511.

Gillot P.Y., Chiesa S., Pasquarè G. \& Vezzoli L. (1982) - <33000 yr K-Ar dating of the volcano-tectonic horst of the Isle of Ischia, Gulf of Neaples. Nature, 229, 242-244.

GRUPPO DI LAVORO MS (2008) - Indirizzi e criteri per la microzonazione sismica. Conferenza delle Regioni e delle Province autonome Dipartimento della protezione civile, Roma, 3 vol. e Dvd.

Grünthal G. (1998) - European Macroseismic Scale 1998. European Seismological Commission, Subcommission on Engineering Seismology, Working Group Macroseismic Scales, Cahiers du Centre Européen de Géodynamique et de Séismologie (ECGS) 15.

Guidoboni E., Ferrari G., Mariotti D., Comastri A., Tarabusi G., Sgattoni G. \& Valensise G. (2018) - CFTI5Med, Catalogo dei Forti Terremoti in Italia (461 a.C.-1997) e nell'area Mediterranea (760 a.C.-1500). Istituto Nazionale di Geofisica e Vulcanologia (INGV). doi: https://doi.org/10.6092/ingv.it-cfti5.

HudSON M., IDRISS I.M. \& BEIKAE M. (2003) - QUAD4M: a computer program to evaluate the seismic response of soil structures using finite element procedures and incorporating a compliant base, Rev. 2003. Center for Geotechnical Modeling Dept. of Civil and Environmental Engineering University of California, Davis, U.S.A.

IERvolino I., Galasso C. \& Cosenza E. (2009) - REXEL: computer aided record selection for code-based seismic structural analysis. Bulletin of Earthquake Engineering, 8, 339-362.

ISSMGE-TC4 (1999) - Manual for zonation on seismic geotechnical hazards. In: Technical committee for earthquake geotechnical engineering, TC4, international society for soil mechanics and geotechnical engineering. The Japanese Geotechnical Society, Tokyo.

Kottкe A. \& Rathje E. (2008) - A Semi-Automated Procedure for Selecting and Scaling Recorded Earthquake Motions for Dynamic Analysis. Earthquake Spectra, 24(4), 911-932

KuHLEMEYER R.L. \& LySMER J. (1973) - Finite element method accuracy for wave propagation problems. Journal of the Soil Mechanics and Foundation Division, 99(5), 421-427.

Licata V., D'Onofrio A., Olivares L. \& Silvestri F. (2014). Liquefazione dei terreni piroclastici: confronto tra approcci semi-empirici e valutazioni basate su prove di laboratorio. Atti del XXV Convegno Nazionale AGI: La Geotecnica nella difesa del territorio e delle infrastrutture dalle calamità naturali. Baveno 4-6 giugno 2014.

Licata V., Forte G., D'Onofrio A., Evangelista L., Jalayer F., Santo A. \& Silvestri F. (2016) - Microzonation study on the Western area of Napoli. Procedia Engineering, 158, 511-516.
Licata V., Forte G., d’Onofrio A., Santo A., Silvestri F. (2019) - A multilevel study for the seismic microzonation of the Western area of Naples (Italy). Bulletin of Earthquake Engineering, 17, 4711-4741.

Luzi L., Puglia R., Russo E. \& ORFEUS WG5 (2016) - Engineering Strong Motion Database, version 1.0. Istituto Nazionale di Geofisica e Vulcanologia, Observatories \& Research Facilities for European Seismology. https://doi.org/10.13127/ESM.

Luzi L., Pacor F., Lanzano G., Felicetta C., Puglia R. \& D’Amico M. (2020) - 2016-2017 Central Italy seismic sequence: strongmotion data analysis and design earthquake selection for seismic microzonation purposes. Bulletin of Earthquake Engineering, 18 5533-5551.

Mancini M., Gaudiosi I., Caciolli M.C., Cavuoto G., Di Fiore V., Milana G., Vassallo M., Silvestri F., D’Onofrio A., Allenza G.A., Pompa P. Coltella M., Cosentino G., Pietrosante A. \& Tarouini E. (2019) - Assessment of site effects in volcanic areas: results from seismic microzonation studies in the island of Ischia (Naples, Italy). GNGTS 2019, Gruppo Nazionale di Geofisica della Terra Solida, Atti del $38^{\circ}$ Convegno Nazionale, 12-14 Novembre 2019, Roma, CNR, 420-423, ISBN 978-88-940442-9-4

Marotta A., Liberatore D. \& Sorrentino L. (2019) - Historical Building Codes issued after the strong Italian earthquakes of Norcia (1859) and Ischia (1883). Annals of Geophysics, 62(3), 337.

McGuIRE R.K. (2001) - Deterministic vs. probabilistic earthquake hazards and risks. Soil Dynamics and Earthquake Engineering, 21(5), 377-384.

Meletti C., Montaldo V., Stucchi M. \& Martinelli F. (2006) - Database della pericolosità sismica MPS04. Istituto Nazionale di Geofisica e Vulcanologia (INGV). https://doi.org/10.13127/SH/MPS04/DB.

Meletti C., Galadini F., Valensise G., Stucchi M., Basili R., Barba S. VANNUCCI G. \& Boschi E. (2008) - A seismic source zone model for the seismic hazard assessment of the Italian territory. Tectonophysics, 450, 85-102.

Mori F., Gaudiosi I., Tarquini E., Bramerini F., Castenetto S., Naso G. \& SPINA D. (2020) - $H_{\text {SM: }}$ a synthetic damage-constrained seismic hazard parameter. Bulletin of Earthquake Engineering, 18, 56315654.

Moscatelli M., Albarello D., Scarascia Mugnozza G. \& Dolce M. (2020) - The Italian approach to seismic microzonation. Bulletin of Earthquake Engineering, 18, 5425-5440.

Moscatelli M., Vignaroli G., Pagliaroli A., Razzano R., Avalle A., Gaudiosi I., Giallini S., Mancini M., Simionato M., Sirianni P., Sottili G., Bellanova J., Calamita G., Perrone A., Piscitelli S. \& LANzo G. (2021) - Physical stratigraphy and geotechnical properties controlling the local seismic response in explosive volcanic settings: the Stracciacappa maar (central Italy). Bulletin of Engineering Geology and the Environment, 80, 179-199

Musson R.M.W., Grünthal G. \& Stucchi M. (2010) - The comparison of macroseismic intensity scales. Journal of Seismology, 14, 413-428. https://doi.org/10.1007/s10950-009-9172-0.

Nappi R., Alessio G., Gaudiosi G., Nave R., Marotta E., Siniscalchi V., Civico R., Pizzimenti L., Peluso R., Belviso P. \& Porfido S. (2018). The 21 August 2017 Md 4.0 Casamicciola Earthquake: First Evidence of Coseismic Normal Surface Faulting at the Ischia Volcanic Island. Seismological Research Letters, 89(4), 13231334, https://doi.org/10.1785/0220180063.

Nappi R., Porfido S., Paganini E., Vezzoli L., Ferrario M.F., Gaudiosi G., Alessio G. \& Michetti A.M. (2021) - The 2017, MD = 4.0, Casamicciola Earthquake: ESI-07 Scale Evaluation and Implications for the Source Model. Geosciences 2021, 11, 44, https://doi.org/10.3390/geosciences11020044.

NTC (2018) - Aggiornamento delle Norme tecniche per le costruzioni. DM 17.1.2018, Ministero delle Infrastrutture e dei Trasporti, Italia, Supplemento ordinario alla "Gazzetta Ufficiale" n. 42 del 20/02/2018, Serie generale.

Oliviero A., Cuccurullo F. \& Verta A. (2019) - Microzonazione sismica di III livello del Comune di Forio. Relazione Illustrativa. Piano degli studi di microzonazione sismica di III livello dei Comuni di Casamicciola, Lacco Ameno e Forio, ai sensi del D.L. 28 settembre, 109 art. 18, comma 1, lettera $h$ (con tavole allegate). http://www. commissarioricostruzioneischia.it/Esiti-Microzonazione.html.

ODCPC (2017) - OCDPC 476 del 29/08/2017. Primi interventi urgenti di protezione civile conseguenti all'evento sismico che ha interessato il territorio dei comuni di Casamicciola Terme, di Forio e di Lacco Ameno dell'Isola di Ischia il giorno 21 agosto 2017 (Gazzetta Ufficiale, n. 204 del 1/09/2017). 
OPCM (2006) - OPCM 3519 del 28/04/2006. Criteri generali per l'individuazione delle zone sismiche e per la formazione e l'aggiornamento degli elenchi delle medesime zone (Gazzetta Ufficiale, n.108 del 11/05/2006)

Pagliaroli A., Moscatelli M., Raspa G. \& Naso G. (2014) - Seismic microzonation of the central archaeological area of Rome: results and uncertainties. Bulletin of Earthquake Engineering, 12(3), $1405-1428$.

Pergalani F., Pagliaroli A., Bourdeau C., Compagnoni M., Lenti L., Lualdi L., Madiai C., Martino S., Razzano R., Varone C. \& Verrubb V. (2020) - Seismic microzoning map: approaches, results, and applications after the 2016-2017 Central Italy seismic sequence. Bulletin of Earthquake Engineering, 18, 5595-5629.

Poli S., Chiesa S., Gillot P.Y., Gregnanin A., Guichard F., Stella R. (1987) - Major and trace element variation versus time in the volcanic products of Ischia (Gulf of Neaples), evidence of successive magmatic cycles. Contributions to Mineralogy and Petrology, 95, 322-335.

Presidenza del Consiglio dei Ministri (2018) - Ordinanza n. 1 del 27 novembre 2018. Assegnazione dei finanziamenti per gli studi di microzonazione sismica di Hl livello ai Comuni di Casamicciola Terme, Forio, Lacco Ameno dell'isola di Ischia a seguito degli eventi sismici del 21 agosto 2017. Presidenza del Consiglio dei Ministri, Commissario Straordinario per la Ricostruzione nei territor dell'isola d'Ischia interessati dal sisma del 21 agosto 2017. http:// www.commissarioricostruzioneischia.it/Ordinanze.html.

Riello G., Petricone A., Di Grazia A., Iannotta A., Miragliuolo F. \& Lotito G. (2019) - Microzonazione sismica di III livello del Comune di Lacco Ameno. Relazione Illustrativa. Piano degli studi di microzonazione sismica di III livello dei Comuni di Casamicciola, Lacco Ameno e Forio, ai sensi del D.L. 28 settembre, 109 art. 18, comma 1, lettera h (con tavole allegate), http://www. commissarioricostruzioneischia.it/Esiti-Microzonazione.html.

Santucci de Magistris, F., d'Onofrio, A., Penna, A., Puglia, R., Silvestri, F. (2014) - Lessons Learned from two Case Histories of Seismic Microzonation in Italy. Natural Hazards, 74(3), 2005-2035.

Sbrana A., Toccaceli R.M. (2011). Isola di Ischia. Foglio 464, Carta Geologica della Regione Campania, scala 1:10.000. Note Illustrative. Regione Campania, Assessorato difesa del Suolo, pp. 216.

Sbrana A., Marianelli P., Pasouini G. (2018) - Volcanology of Ischia (Italy). Journal of Maps, 14(2), 494-503.

SeEd H.B., Idriss I.M. (1970) - Soil Moduli and Damping Factors for Dynamic Response Analyses. Report EERC 70-10, Earthquake Engineering Research Center, University of California, Berkeley, U.S.A.

Selva J., Azzaro R., Taroni M., Tramelli A., Alessio G., Castellano M., Ciuccarelli C., Cubellis E., Lo Bascio D., Porfido S., Ricciolino
P., Rovida A. (2021) - The Seismicity of Ischia Island, Italy: An Integrated Earthquake Catalogue From 8th Century BC to 2019 and Its Statistical Properties. Frontiers in Earth Science, 9 (629736), https://doi.org/10.3389/feart.2021.629736.

SIEBERG A. (1912) - Über die makroseismische Bestimmung der Erdbebenstärke. Gerlands Beitr Geophys., 11, 227-239.

SM Working Group (2015) - Guidelines for Seismic Microzonation Conference of Regions and Autonomous Provinces of Italy - Civil Protection Department, Rome.

Stucchi M., Meletti C., Montaldo V., Crowley H., Calvi G.M. \& Bosch E. (2011) - Seismic Hazard Assessment (2003-2009) for the Italian Building Code. Bulletin of the Seismological Society of America 101(4), 1885-1911.

Tibaldi A. \& Vezzoli L. (1998) - The space problem of caldera resurgence: an example from Ischia Island, Italy. Geologische Rundschau, 87, 53-66

Tibaldi A. \& Vezzoli L. (2004) - A new type of volcano flank failure: The resurgent caldera sector collapse, Ischia, Italy. Geophysical Research Letters, 31, L14605

Toscano A., Cuccurullo F. \& D'Anna A. (2019) - Microzonazione sismica di III livello del Comune di Casamicciola Terme. Relazione Illustrativa. Piano degli studi di microzonazione sismica di III livello dei Comuni di Casamicciola, Lacco Ameno e Forio, ai sensi del D.L. 28 settembre, 109 art. 18, comma 1, lettera h (con tavole allegate) http://www.commissarioricostruzioneischia.it/EsitiMicrozonazione.html.

Verderame G., Del Gaudio C., Di Domenico M. \& Ricci P. (2017) Rapporto relativo ad una preliminare predizione del danno agli edifici residenziali di Casamicciola Terme e Lacco Ameno a seguito del sisma del 21.08. 2017, ore 20.57, M=4.0. Dipartimento di Strutture per l'Ingegneria e l'Architettura - DiSt Università degli Studi di Napoli Federico II, RELUIS. https://doi.org/10.13140/ RG.2.2.35815.55202.

Vezzoli L. (1988). Island of Ischia. CNR Quaderni de 'La Ricerca Scientifica', 114, Progetto Finalizzato 'Geodinamica', Monografie finali, 10, pp. 134.

Vezzoli L., Principe C., Malfatti J., Arrighi S., Tanguy J-C. \& Le GoFf M. (2009) - Modes and times of caldera resurgence: The $<10 \mathrm{ka}$ evolution of Ischia Caldera, Italy, from high-precision archaeomagnetic dating. Journal of Volcanology and Geothermal Research, 186, 305-319.

VINALE F. (1988) - Caratterizzazione del sottosuolo di un'area campion di Napoli ai fini di una microzonazione sismica. Rivista Italiana di Geotecnica, 22(2), 77-100.

Vucetic M. \& Dobry R. (1991) - Effect of soil plasticity on cyclic response. Journal of the geotechnical Engineering Division, ASCE, 17(1), 89-107. 